\title{
Scholastic Sufism of the Alexandrian Shādhiliyya
}

\section{The Egyptian Context}

[Al-Wāsițī] performed the greater pilgrimage and joined a circle of [Shāfíī jurists] in Mecca. For a period of time he lived in some of the Sufi convents (khawāniq) in Cairo, where he [also] associated with circles of jurists. However, his heart was not reassured by anything of the modern [Sufi] groups (al-țawäif) [he found there]. He joined the Shādhiliyya group in Alexandria and found that they had what he was looking for, pertaining to gleams of experiential knowledge (ma'rifa), divine love (mahabba), and a method for the spiritual path (sulük). Hence, he acquired that from them and benefited from them, and followed their way and their guidance. ${ }^{1}$

Thus Ibn Rajab sums up a significant part of al-Wāsițīs life, which covers the moment he decided to leave Iraq to the years he spent in Egypt. I say significant because his experiences in Egypt would leave a lasting impression on him and strongly influence the writings he would later produce in Damascus. Both his association with the Alexandrian Shädhiliyya, the țầifa named after the Moroccan Sufi Abū al-Ḥasan 'Alī al-Shādhilī (d. 656/1258), and his time spent in Cairene Sufi convents, were essential components in the final shaping of his interpretation of Sufism. The current chapter is dedicated to his Alexandrian era, which we will again study through his autobiography and other relevant primary sources. Before we can do so, there are two issues regarding our source material that we must briefly address.

First, contrary to Ibn Rajab's account, al-Wāsițīs autobiography tells us that he actually joined the Shādhiliyya in Alexandria before he tried his luck in Sufi convents, with no mention of these being Cairene, or of Cairo at all for that matter. We can nevertheless assume that his account of the time he lived in Sufi convents concerns the period he spent in Cairo as related by Ibn Rajab above. In the following pages we will naturally follow the chronology provided by al-Wāsiți himself in his autobiography, and start with his description of the Shādhiliyya. We will turn to his Cairene days in the next chapter.

1 Ibn Rajab, Dhayl, vol. 4, p. 381. 
Second, the sources reveal practically nothing about the dates of al-Wāsițîs travels, so that it is impossible to say exactly how long he stayed where. Although our Iraqi Sufi himself makes no mention at all of Mecca, he may very well have stayed there for a considerable time. As we have seen, he left Iraq around 683/1284, and most likely entered Alexandria somewhere after 686/1287, the year in which Abū al-Abbās Aḥmad al-Mursī died. ${ }^{2}$ When alWāsiți made his switch from Alexandria to Cairo is also impossible to say, but we can make an approximate estimation of the year he left Cairo. In his Mukhtașar sìrat rasūl Allāh he states that he traveled for almost fifteen years, searching for the most sound pathway to God, until he finally found it in Damascus. ${ }^{3}$ Calculating from the approximate date he left Iraq, we can thus estimate that he was in Damascus around the year 698/1299. This is supported by al-Dhahabī's Tārīkh wherein we find that al-Wāsiți once met with the Sufi Badr al-Dīn Ḥasan Ibn Hūd, whom we know lived in Damascus, where he passed away in 699/130o. ${ }^{4}$ Hence, our Iraqi Sufi would had to have entered the Syrian capital some time before that.

With this estimated timespan we now commence with al-Wāsițīs Alexandrian years. This chapter is divided into two parts. The first part will provide contextual background to early Mamluk Alexandria, a city that is far too often neglected in the study of Sufism. The second part makes up the bulk of this chapter and focuses specifically on al-Wāsițịs account of the Shādhiliyya. The latter section will not only help us understand al-Wāsițīs own formulation of Sufism as studied in part 2 of this book, but also provide new details on the early Shādhiliyya.

\subsection{Stagnation and War}

Named after the Macedonian king Alexander the Great, the city of Alexandria (al-Iskandariyya in Arabic) had become part of the early Muslim empire under the second caliph, 'Umar b. al-Khaț̣āb. Almost seven centuries later, when alWāsițī reached the city, it was part of the Baḥrī Mamluk domains, which roughly encompassed what is today Egypt, Syria, Lebanon, Jordan, and Palestine, and also controlled the Hijaz. In spite of Alexandria's relative prosperity in comparison with previous centuries, it was at that time in the process of losing its significance as a regional political and administrative center. It may,

2 Since al-Mursī had been the Shādhilī shaykh of Alexandria, and everything indicates that alWāsițī only got to meet al-Mursì's pupils, but never the shaykh himself, he probably entered Alexandria only after his passing.

3 Al-Wāsițī, Mukhtașar sīrat rasūl Allāh, Manuscript in Leiden University: Or. 482, f.2b.

4 Al-Dhahabī, Tārīkh, vol. 52, p. 401. Ibn al-'Imād, Shadharāt, vol. 7, p. 78o. On Ibn Hūd, see for instance: Kraemer, “The Andalusian Mystic," pp. 59-73. 


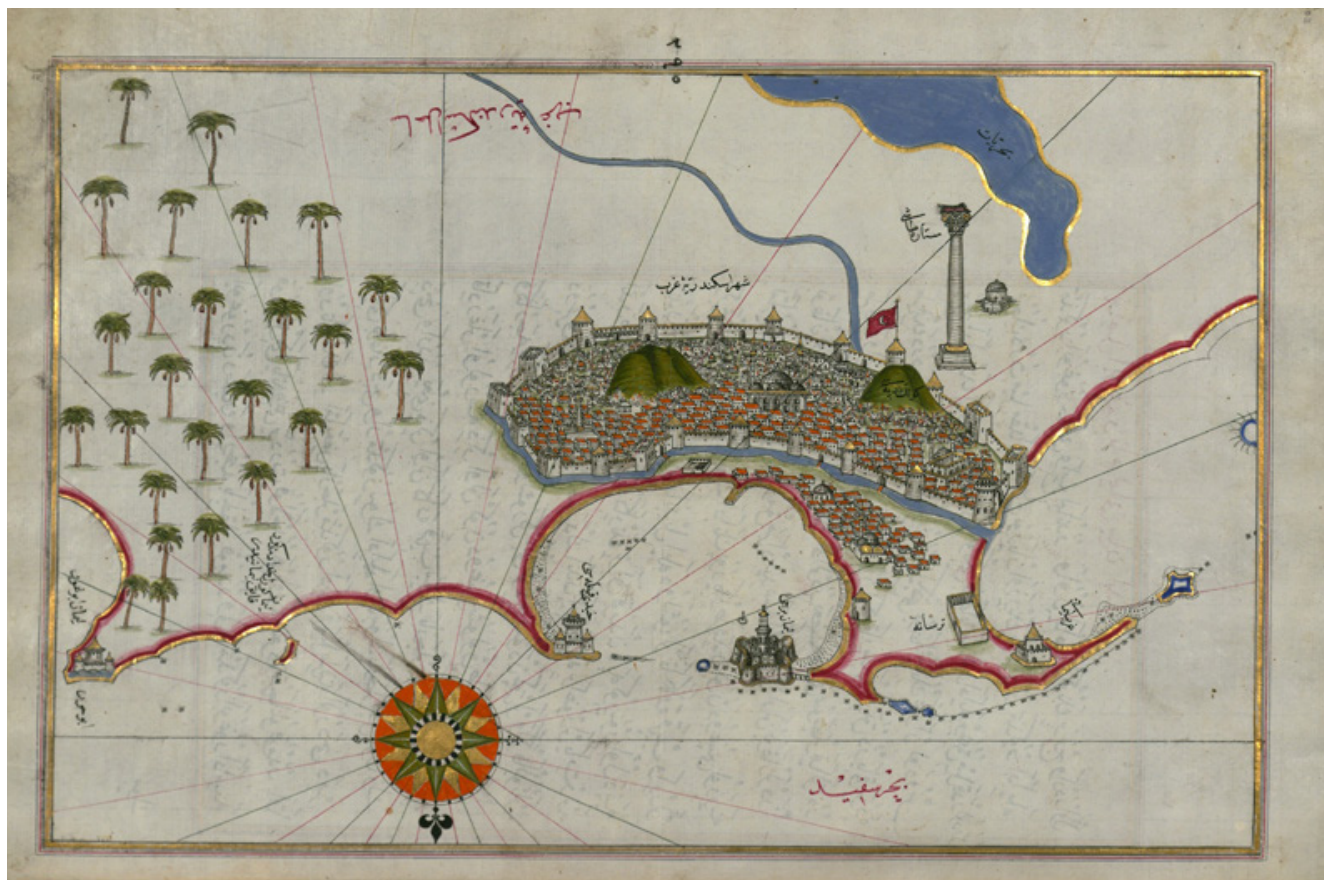

FIgURE 7 An Ottoman impression of Alexandria dating from 1525, Piri Preis, Kitāb-i Bahriye, W.658: f. 302A.

(C) THE WALters ART MUSEUM, Baltimore

then, come as somewhat of a surprise that during this very period of economic and institutional stagnation, the city was at the same time transforming into one of the most important centers of Sufism in Egypt. Since an understanding of this transformation will be of relevance to the current chapter, we will go through several historical developments that were at the heart of this matter, and thereby simultaneously provide the necessary context to al-Wāsițīs time among the Shādhiliyya.

Our Iraqi Sufi's journey into Mamluk lands probably went via the pilgrimage route from Baghdad to Mecca, and from Mecca to Alexandria, between which he may have passed through Cairo for the first time as well. ${ }^{5}$ Reaching Alexandria by land must have been an impressive sight. It is related that the white, massive walls that surrounded its old center made it appear as a bright shining city. Outside the walls there were several suburbs and graveyards to be found. Barren desert was not far away, but there was also fertile land around

5 For the pilgrimage routes, see: William C. Brice, An Historical Atlas of Islam (Leiden: E.J. Brill, 1981), p. 22. 
Alexandria, most notably to its south near Lake Maryūt, where one would find agricultural areas and recreational gardens. The city's southern gate, the Bāb al-Sidra, served as the main entrance through which travelers from Fusțât (Old Cairo) would enter. Inside the walls was the political center near the western gate, the Bāb al-Akhdiar. Commerce and industry was concentrated along the Mahajja avenue, which ran from the eastern gate, the Bāb al-Rashīd, to the city center. ${ }^{6}$ As we shall see, al-Wāsiți would probably have spent most of his time outside the walls in the northern quarter of Alexandria, which started from the sea gate, the Bāb al-Bahrr, to the city's northern extremity. There were ports on both sides of this quarter, with the western one catering to Muslim ships, and the eastern one to non-Muslim ships. Needless to say, as Alexandria's landing place for traders and merchants from many corners of the world, this was a multiethnic and multireligious environment. ${ }^{7}$ Organized in kinds of guilds, groups of merchants had their own warehouses, or funduqs, from where they ran their businesses. And business was good indeed. The merchants of Alexandria accumulated a great deal of wealth, to the extent that some families became true merchant dynasties. ${ }^{8}$

Now, one would expect that the city itself prospered tremendously under the booming business of these international traders. This, however, was not the case. As a gateway between the Middle East, the northern Mediterranean, and the Islamic occident, Alexandria was indeed of vital importance to the trade of Egypt. But that was precisely the problem; because Fusțāt had been transformed into the major marketplace of Egypt in this epoch, the country's maritime cities came to function as stops on the road to the center. Already from the Ayyubid period onwards, Alexandria's own interests were subjugated to those of the sultanate, so that its sole role became that of Egypt's major port city. As such, local interests were not only regarded as inferior to those of the sultanate, but even as potentially harmful to the prosperity of the capital. ${ }^{9}$

Through their respective studies of the Geniza documents, both Abraham L. Udovitch and Miriam Frenkel have provided exceptionally valuable

6 Doris Behrens-Abouseif, "Topographie d'Alexandrie médiévale," in Alexandrie médiévale 2, ed. Christian Décobert (Cairo: Institut Français d'Archéologie Orientale, 2010), p. 114,

7 Miriam Frenkel, "Medieval Alexandria: Life in a Port City," al-Masāq:Journal of the Medieval Mediterranean, 26:1, (2014): pp. 9-20, and p. 27. For a map of Alexandria that shows the locations of the several names mentioned here, see p. 77 .

8 Subhi Labib, R. Guest \& C. Edmund Bosworth, "Alexandria (al-Iskandariyya; in EI1, alIskandarìya)," in Historic Cities of the Islamic World, ed. C. Edmund Bosworth (Leiden/Boston: E.J. Brill, 2007), pp. 19-20, and Christian Décobert, "Alexandrie au XıIIe siècle: Une nouvelle topographie," in Alexandrie médiévale 1, ed. Christian Décobert and Jean-Yves Empereur (Cairo: Institut Français d'Archéologie Orientale, 1998), p. 76.

9 Décobert, “Alexandrie au Xııı siècle," pp. 78-79, and Labib et al. “Alexandria," p. 20. 
contributions to our knowledge of this development that started around the middle of the fifth/eleventh century. ${ }^{10}$ Udovitch's reading of the Geniza has revealed that important transactions would take place in Cairo rather than Alexandria, so that the latter city served as a point of entry and departure, but not exchange. Prices were apparently higher in Alexandria as well, while commodities from Cairo appear to have generally been regarded as being of a higher quality, to the extent that one Alexandrian wrote about his city that: "nothing is worthwhile buying here."11 While Frenkel corroborates this image, she argues that it would be unjust to subsequently view Alexandria as a peripheral city. Instead she opts to view it as a "gateway city," a term she borrows from urban geographers. In contrast to central cities, she explains, gateway cities develop between areas of production on a site of transportational significance. They are characterized by long-distance trade and are dependent on central cities for their products. ${ }^{12}$

Besides having transformed into a gateway city under pressure of the Ayyubid economic policy, the Alexandria al-Wāsițī saw had been deeply affected by another event of the preceding two centuries: the Crusades. Its location at the Mediterranean Sea made it one of the main maritime entrances into the Muslim world from Europe, and thus strategically important as a frontier city (thaghr) to both the Ayyubid sultans and their Mamluk successors. ${ }^{13}$ Famous in the West as Saladin, the first Ayyubid ruler Șalāh al-Dīn (r. 570-589/11741193) visited the city several times and put in considerable effort to strengthen its fortifications against the European Crusaders. He had already dealt with two Crusader sieges at Alexandria before his ascension to the throne, and was thus bent on reconstructing its walls and towers, something which would continue well into the Bahrī Mamluk era. With his eyes on an invasion from Europe, he also invested in the city's religious resources, such as Sufi convents, madrasas, and mosques, in order to unify his kingdom under the banner of

10 The Cairo Geniza is a repository with centuries-old documents that were found in an old Cairene synagogue in the previous century. Because the variety of its religious and secular texts may contain the name(s) of God, it was stored so as to be preserved from desecration, cf. Abraham L. Udovitch, "Alexandria in the 11th and 12th Centuries. Letters and Documents of the Cairo Geniza Merchants: an Interim Balance Sheet," in Alexandrie médiévale 2, ed. Christian Décobert (Cairo: Institut Français d'Archéologie Orientale, 2010), p. 99.

$11 \quad$ Ibid. p. 101.

12 Frenkel, "Medieval Alexandria," p. 34.

13 Martina Müller-Wiener, Eine Stadtgeschichte Alexandrias von 564/1169 bis in die Mitte des 9./15. Jahrhunderts: Verwaltung und innerstädtische Organisationsformen (Berlin: Schwarz, 1992), p. 2. 
Sunni Islam. ${ }^{14}$ Despite Șalāḥ al-Dīn's measures, instability soon increased after his passing, as the Ayyubid dynasty was not only facing foes from outside, but was also dealing with internal strife. ${ }^{15}$

Although the Mamluk sultans likewise had their fair share of internal conflicts, and Egypt and Syria were under almost constant threat from both Crusader and Mongol invaders, the second half of the seventh/thirteenth century was a somewhat more stable period for Alexandria. The Mamluk sultan al-Malik al-Z̄āhir Rukn al-Dīn Baybars I (r. 658-676/126o-1277) was a brilliant strategist who, like Șalāḥ al-Dīn, effectively employed religion as a means to stabilize his realm. For instance, in 661/1262 he forbade taverns, wine presses, and hashish, and cleared the city of prostitutes. ${ }^{16}$ He thereby displayed his role as the upholder of proper religious morality and the protector of Islam, and simultaneously emphasized the city's religious character. In 671/1272 there were new rumors of another imminent Christian attack on Alexandria which proved false in the end, but nevertheless motivated Baybars to provide it with extra reinforcements. ${ }^{17}$

When al-Wāsițī entered the city, it was relatively peaceful under the rule of Sultan al-Malik al-Manșūr Sayf al-Dīn Qalāwūn (r. 678-689/1279-129o). The latter understood very well that wars could not be won without revenues. Since the sultanate lacked its own commercial fleet, he sought to increase trade by making Alexandria attractive for European merchants. Alexandria thus remained the most important port of Egypt, as the place where Christian merchants from across the Mediterranean traded and ran their own funduqs, and where embassies of European powers arrived and embarked, and treatises with them were made. ${ }^{18}$ Christian merchants were well received and the city's governor was intructed to provide their funduqs with protection at all times, in particular on Fridays when Alexandria's Muslim population gathered for the jumu'a prayer. Qalāwūn, in turn, received taxes from them which, among other things, enabled him to invest in the Mamluk army. ${ }^{19}$ The favorable effects of Qalāwūn's trade policy on Alexandria were felt well after his passing. For

14 Müller-Wiener, Eine Stadtgeschichte Alexandrias, p. 17 and p. 263; Hofer, The Popularisation of Sufism, p. 40.

15 Décobert, "Alexandrie au XıIIe siècle," pp. 72-74.

16 Peter Thorau, The lion of Egypt: Sultan Baybars I and the Near East in the thirteenth century (London: Longman, 1992), p. 196.

17 Ibid. p. 224.

18 European merchants would come from such places as Genoa, Venice, Pisa, Ragusa, Provence, and Catalonia. See for instance: Labib et al. "Alexandria," p. 18.

19 Linda S. Northrup, From slave to sultan: the career of al-Manșūr Qalāwūn and the consolidation of Mamluk rule in Egypt and Syria (678-689 A.H./1279-129o A.D.) (Stuttgart: Franz Steiner Verlag, 1998), pp. 282-294. 
instance, when the Nile was low in 694/1295 and pestilence and famine broke out in Egypt, Alexandria benefited from the grains it was able to import from across the Mediterranean, which was owed to the sultan's good relations with Frankish lands. ${ }^{20}$ Yet, we must note that in the same year Sultan al-Malik alNāṣir Nāșir al-Dīn Muhammad (1st r. 693-694/1294-1295) sent his highestranking emir to Alexandria to deal with Frankish piracy around the coast. ${ }^{21}$ This shows that while al-Wāsițī certainly lived in a more or less stable Alexandria, the whole of the seventh/thirteenth century can nonetheless be characterized by continuous vigilance towards the possibility of Frankish raids or attacks.

\section{$1.2 \quad$ Egypt's Sufi Capital?}

We have thus far seen that seventh-/thirteenth-century Alexandria saw a change in its economical and institutional functioning. In both instances this was connected to a larger scheme of developments in Egypt. Intertwined with this was another important development that can help us understand why alWāsițī may have been drawn to Alexandria. The current section will demonstrate that the religious landscape of the maritime city in his time had transformed considerably to the point that it was one of Egypt's main Sufi centers, and perhaps for a certain period even its Sufi capital, thereby overshadowing Cairo.

Sufism already played an important role in the religious policy of the Ayyubids and continued to do so under the Mamluks. Besides the many examples that we have of sultans and emirs who, seemingly driven by genuine spiritual concerns, attached themselves to Sufi shaykhs or displayed deep reverence for pious figures, we can also discern a political dimension to their involvement with Sufism. ${ }^{22}$ In the context of Alexandria this can be seen for the first time under Salāh al-Dīn who, as mentioned earlier, invested in the city's religious resources as part of his agenda to propogate Sunni Islam as the Ayyubid

20 Peter M. Holt, Early Mamluk diplomacy (1260-1290): treaties of Baybars and Qalāwūn with Christian rulers (Leiden: Brill, 1995), p. 28.

21 Donald P. Little, An introduction to Mamlük historiography: an analysis of Arabic annalistic and biographical sources for the reign of al-Malik an-Nāșir Muhammad ibn Qalä'ūn (Wiesbaden: Franz Steiner Verlag, 1970), p. 4.

22 Many scholars have pointed to the relations between officials and Sufis, see for instance: Geoffroy, Le Soufisme, p. 123-127; Müller-Wiener, Eine Stadtgeschichte Alexandrias, p. 24; Décobert, "Alexandrie au XıIIe siècle," p. 80 and p. 93; Alexander D. Knysh, Ibn 'Arabi in the Later Islamic Tradition: The Making of a Polemical Image in Medieval Islam (Albany: State University of New York Press, 1999), 51; see also the references of Hofer concerning the spiritual concern of the Ayyubids and Mamluks, in: The Popularisation of Sufism, pp. 49-50, and 59 . 


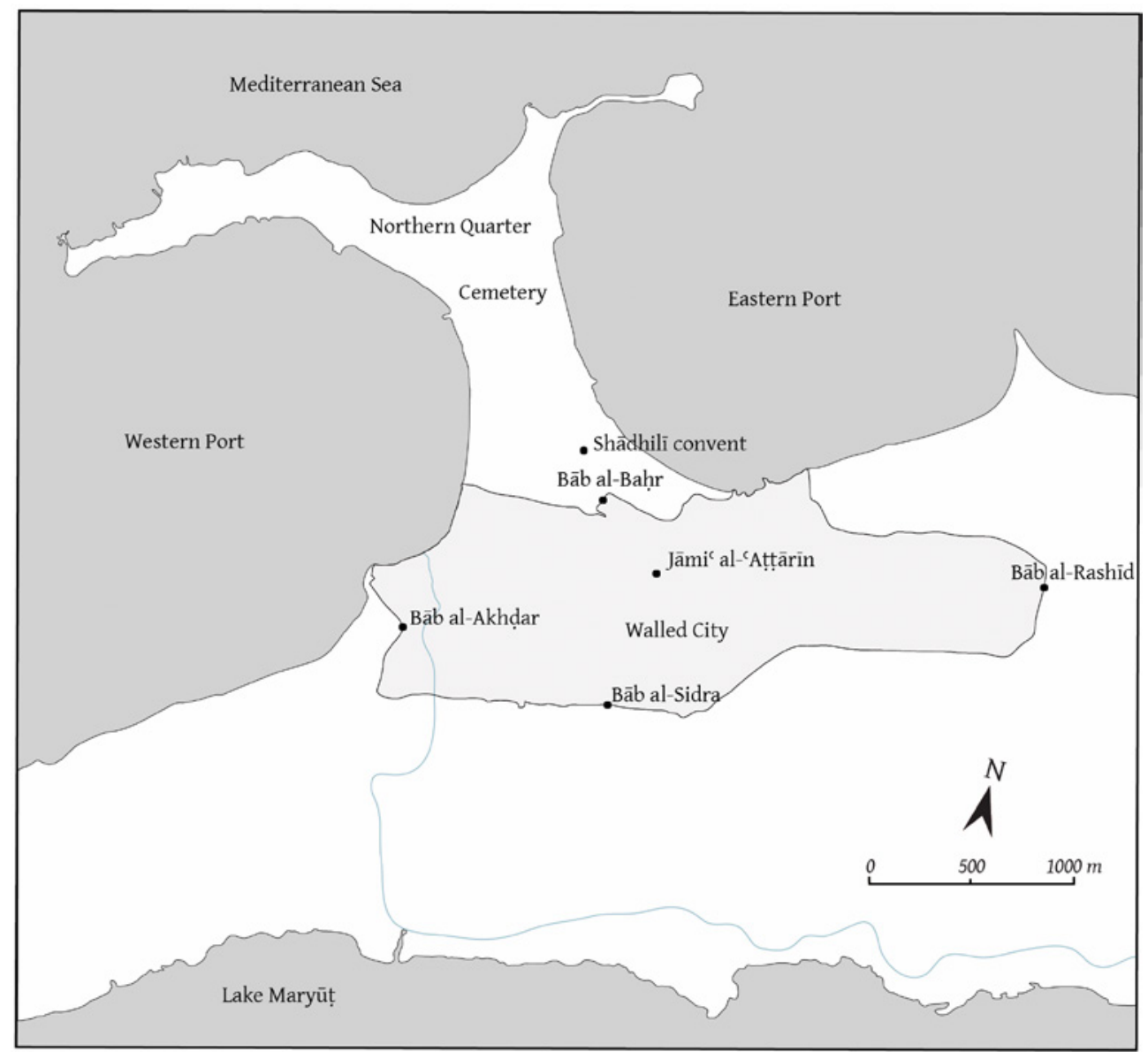

FIGURE 8 Seventh/thirteenth-century Alexandria with the approximate location of the earliest Shādhilī convent. Map adapted from Behrens-Abouseif, "Topographie," p. 126

ideology. One of these investments was the establishment and sponsoring of khānqāhs (sing. khānqāh, pl. khawāniq), the Persian word for Sufi convents. Both the Ayyubids and the Mamluks were favorably disposed towards organized Sufi groups and utilized the convents they sponsored to spread a sharíabased spirituality that anchored Sufism in Sunni scripturalism. One would thus find that, besides the science of tașawwuf, Islamic law would be taught at these khānqāhs. ${ }^{23}$

23 Geoffroy, Le Soufisme, pp. 166-167; Éric Geoffroy, "Les milieux de la mystique musulmane à Alexandrie aux Xıııe et XIVe siècles," in Alexandrie médiévale 2, ed. Christian Décobert 
At the same time, the Mongol conquest and the Reconquista in al-Andalus brought to Egypt an influx of foreigners from the east and the west of the Muslim world, among whom many were affiliated with Sufi shaykhs from their native lands, or were even themselves considered as spiritual masters. ${ }^{24}$ While this was certainly not Egypt's earliest contact with Sufism, this did introduce new and different manifestations of the Sufi path. ${ }^{25}$ In Iraq, the emergence of the first true Sufi orders that traced their origins to a particular shaykh with a particular method was already a known phenomenon, as we have seen with the Rifā'iyya in al-Wāsițīs birthplace, for instance. However, it is not exactly clear when this trend started to take root in Egyptian soil. It may very well have been the importation of Iraqi Sufism that came with immigrants hailing from the still recently fallen eastern caliphate that instigated the rapid rise of distinct Sufi orders in Egypt from roughly the second half of the seventh/thirteenth century onwards. A good example of this is found in the Iraqi Rifā'i shaykh Abū al-Fath al-Wāsițī (d. ca. 632/1234), who settled in Alexandria to spread the Rifā̄i order.

However, most newcomers to Alexandria did not come from the fallen caliphate, but from the Maghrib and al-Andalus. For centuries Alexandria had already been an important stop on the hajj pilgrimage route for Muslims coming from the west, some of whom would end up settling in the city. ${ }^{26}$ It is very well possible that its position as a frontier city during the Crusades also attracted especially western Sufis, driven by a pious sense of duty to defend the faith in jihād against the Franks. This would certainly not have been an alien sentiment to the great numbers that were forced to flee from the Reconquista. It is thus claimed, for instance, that the Moroccan shaykh Abū al-Hasan alShādhilī, who had settled in Alexandria in $642 / 1244$, fought alongside his disciples during the 648/125o battle of Manșūra against the Crusaders. ${ }^{27}$ Besides

(Cairo: Institut Français d'Archéologie Orientale, 2010), p. 170; Décobert, "Alexandrie au Xiıre siècle," pp. 8o-81; Hofer, The Popularisation of Sufism, p. 41; Th. Emil Homerin, "Saving Muslim Souls: The Khānqāh and the Sufi Duty in Mamluk Lands," MSR III (1999): p. 66.

24 Hofer, The Popularisation of Sufism, p. 250.

25 Th. Emil Homerin, "Sufis and their Detractors in Mamluk Egypt," in: Islamic Mysticism Contested: Thirteen Centuries of Controversies and Polemics, ed. Frederick de Jong \& Bernd Radtke (Leiden, Netherlands: Brill, 1999), p. 246, where the author also refers us to a list of Egyptian Sufis presented in Jalāl al-Dīn 'Abd al-Raḥmān b. Abī Bakr al-Suyūṭī, Ḥusn al-muhạdạa fì tārīkh Mișr wa-al-Qāhira, ed. Muḥammad Abū al-Fạ̣l Ibrāhīm (Cairo: Dār ihyāà al-kutub al-'arabiyya, 1967), vol. 1, pp. 511-530.

26 Geoffroy, "Les milieux," p. 169.

27 Geoffroy states that it is related that even as al-Shādhilī was nearly blind, he participated in the battle of Manșūra. However, the two earliest biographies dedicated to the shaykh, 
holy war, many North African and Andalusi seekers of the spiritual path were undoubtedly attracted to Alexandria because of the renowned masters of the western Sufi tradition that lived there. The school of the legendary Andalusi Sufi sage Abū Madyan Shu'ayb (d. 594/1198) entered Alexandria with the coming of his disciple, 'Abd al-Razzāq al-Jazūlī (d. 595/1198), who spent the remainder of his life there. ${ }^{28}$ The well-known Risāla of Șafĩ al-Dīn Ibn Abī al-Manșūr (d. 682/1283) provides biographical entries for eight of al-Jazūlì's disciples he met in Alexandria, all of whom he considered masters in their own right. ${ }^{29}$ While he must not have met al-Jazūlī's most famous pupil, Abū Muhammad Șāliḥ b. Yanșarān al-Mājirī (d. 631/1234), we know that he too stayed in Alexandria for twenty years and had a considerable following. ${ }^{30}$

The influence that these historical circumstances had on Alexandria's religious sphere was visible on multiple levels. When it came to jurisprudence, the strong presence of Muslims from the west ensured the dominance of the Mālikī school, although there was also a visible Shāfici community. In theology, adherents of both madhhabs ascribed mostly to the Ash'arī school. ${ }^{31}$ With regard to the science of tasawwuf, we find that Alexandria's Sufis were able to successfully form networks around numerous authoritative spiritual masters; and thanks to the government's favorable stance towards Sufism, several of these shaykhs were well facilitated to spread their teachings. The above-mentioned Rifā̄ī shaykh al-Wāsițī was thus able to teach the Sufi way from Alexan-

Lațāif al-minan and Durrat al-asrār, do not explicitly mention this, nor the battle for that matter. Both works do contain an anecdote that places al-Shādhilī in Manșūra, with Durrat al-asrār adding that he expressed his worry about the safety of Alexandria, which, I would argue, does suggest that the reader is expected to be aware of the context of the Crusader invasion. See: Muḥammad b. Abī al-Qāsim Ibn al-Ṣabbāgh, Kitāb Durrat al-asrār wa-tuhfat al-abrār (Tunis: Mațba'at al-tūnisiyya al-rasmiyya, 1886), pp. 147-148, and: Tāj al-Dīn Aḥmad Ibn 'Ațā̄' Allāh al-Iskandarī, Latạiif al-minan fì manāqib al-Shaykh Abī al'Abbās al-Mursī wa-shaykhihi al-Shādhil̄ Abì al-Hasan, ed. Khalīl 'Imrān al-Manșūr (Beirut: Dār al-Kutub al-'Ilmiyya, 2005), p. 9o, and: Geoffroy, "Les milieux," p. 170.

28 Geoffroy, "Les milieux," p. 171.

29 Șafì al-Dīn al-Ḥusayn al-Azdī Ibn Abī al-Manșūr, La risāla de Ṣafíal-Dīn Ibn Abī al-Manșūr Ibn Zāafir: biographies des maîtres spirituels connus par un cheikh égyptien du viIe-XIIIe siècle, ed. \& trans. Denis Gril (Cairo: Institut français d'archéologie orientale du Caire, 1986), pp. 99b-102b.

30 On al-Jazūīi, see Abū Ya'qūb Yūsuf al-Tādilī, al-Tashawwuf ilā rijāl al-tașawwuf wa-akhbār Abī al-'Abbās al-Sabtī, ed. Aḥamd al-Tawfīq (Rabat: Manshūrāt kulliyyat al-ādāb, 1997), p.327. Al-Mājirī was still alive when al-Tādilī (d. 617/1220) wrote the latter work, and is described by him as one of the greatest shaykhs of his time; see al-Tashawwuf, p. 41. On al-Mājirī, see also: Khayr al-Dīn al-Ziriklī, al-Ađ'ām: qāmūs tarājim li-ashhar al-rijāl wa-alnisā' min al-'arab wa-al-mustáribīn wa-al-mustashriqīn (Beirut: Dār al-iilm al-malāyīn, 2002), vol. 3, p. 199.

$31 \quad$ Labib et al. "Alexandria," p. 17. 
dria's grand mosque, Jāmi al-'Atțāāīn, as was al-Shādhilī and his successor, Abū al-'Abbās al-Mursī, after him. ${ }^{32}$ Furthermore, the sultanate provided al-Jazūī as well as al-Shādhilī with housing in towers of the city's northern walls, and the latter even appears to have been granted space in the citadel (qal'a) to use as his Sufi convent. ${ }^{33}$ There are in fact many more examples of Sufi shaykhs who were in some way honored by Ayyubid and Mamluk officials. Al-Jazūlì's disciple Wajīh al-Dīn Ibn 'Awf was the imam of Alexandria's main mosque and was visited by the Ayyubid sultan Șalāh al-Dīn. ${ }^{34}$ The famous Alexandrian Sufi Abū al-Qāsim al-Qabbārī (d. 662/1264) became so widely noted as a pious man that he was visited by the Mamluk sultan Baybars I and several Mamluk notables. ${ }^{35}$ All of this tells us that by the middle of the seventh/thirteenth century Alexandria had not only become a safe haven for Sufis, but in fact one of the most important - if not the most important - centers of Sufism in Egypt. ${ }^{36}$

Another aspect of this development that we must touch upon briefly here is the change in Alexandria's sacred topography through the establishments of independent convents. Although by no means clear-cut, the period under consideration appears to have known something of a distinction between the "state-sponsored" khānqāh type convent and the self-sufficient ribāt or zāwiya type convent. ${ }^{37}$ We can thus observe that while the khänqāhs were certainly put to use by the city's Sufis, there were also several shaykhs who were able to start their own convents without any help or interference from the sultanate. The majority of these convents were located in Alexandria's northern quarter, just outside the city walls near the Bāb al-Bahr. This is where one could find the ribāts of the Shādhilī Abū al-'Abbās al-Mursī, the Rifāī al-Wāsițī, and the convent of Abū 'Abd Allāh al-Shātịīi, the successor of the Alexandrian Sufi master

32 On the history of this mosque in Alexandria, see Behrens-Abouseif, "Topographie," pp. 121-122. On Sufis teaching in the mosque, see: Ibn al-Ṣabbāgh, Kitāb Durrat al-asrār, p. 147; Geoffroy, "Les milieux," p. 177.

33 Ibn al-Ṣabbāgh, Durrat al-asrār, p. 14 and p. 147.

34 Ibn Abī al-Manșūr, La risāla, p. 102b.

35 Décobert, "Alexandrie au Xıııe siècle," p. 84.

36 It is noteworthy to point to the fact that out of the 155 Sufi authorities named by Șafi alDīn in his Risāla, at least 30 were from Alexandria or were based there for a considerable time. I owe this observation to Décobert, "Alexandrie au XIIIe siècle," p. 84, where he refers to Ibn Abī al-Manșūr, La risāla, pp. 98-110.

37 Geoffroy, Le Soufisme, pp. 168-171, and Décobert, "Alexandrie au XIIIe siècle," p. 93; Hofer, The Popularisation of Sufism, p. $5^{2}$. It must be noted that the classical sources are not always clear when it comes to both the terms used to refer to religious instututions and the roles allotted to them. On this, see also: Jonathan Porter Berkey, The Transmission of Knowledge in Medieval Cairo: A Social History of Islamic Education (Princeton, N.J.: Princeton University Press, 1992), pp. $48-5$ o. 


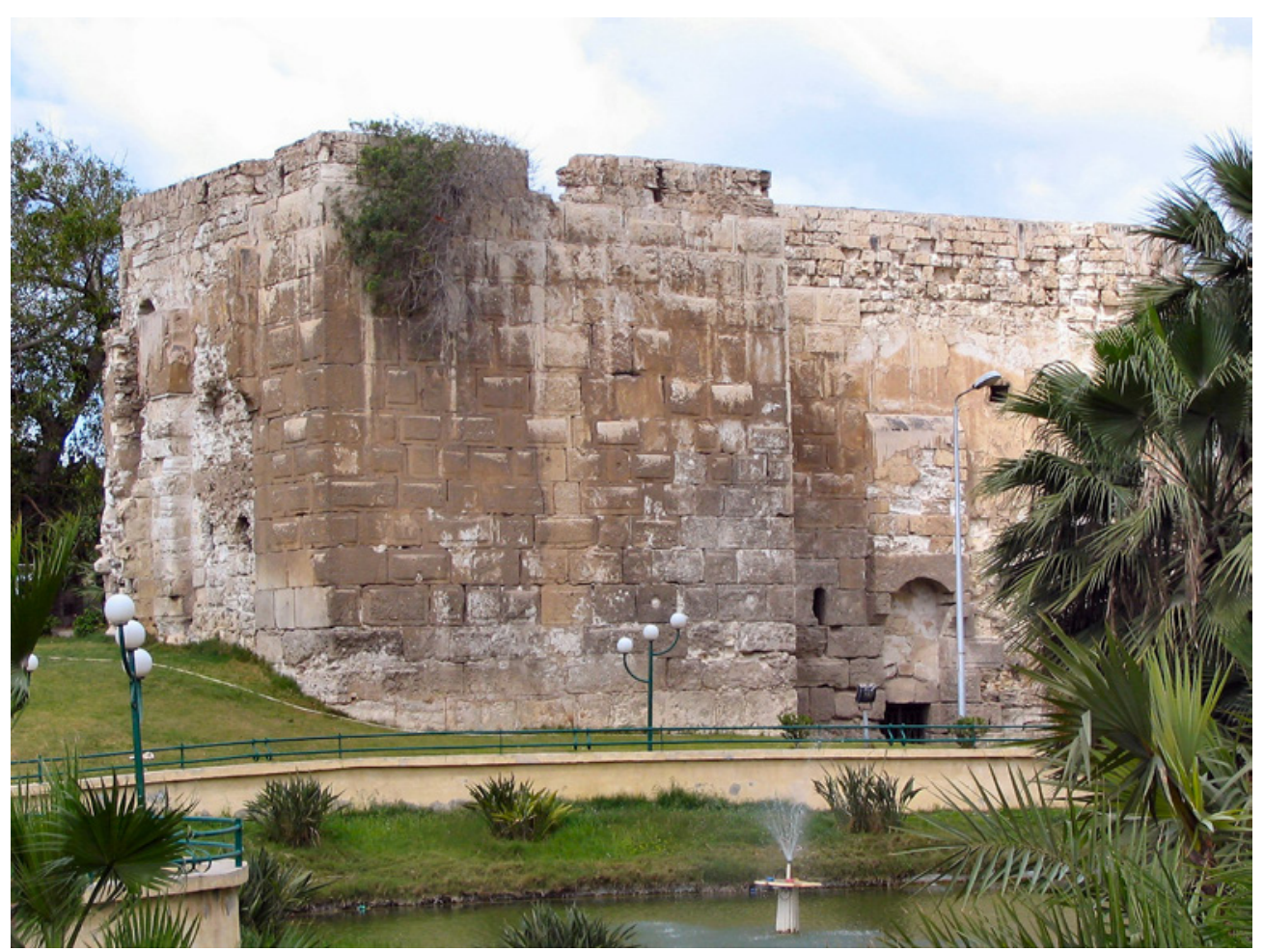

FIGURE 9 Remains of the northeastern corner tower of Alexandria's walls. On its right used to be the Bāb Rashīd. (c) Andrew Michael Chugg, <http://www.alexanderstomb. com>

Aḥmad Abū al-'Abbās al-Ra's (d. 615/1218). ${ }^{38}$ In many cases such enterprises would be financed with the help of a wealthy Alexandrian merchant who attached himself to a spiritual master. This was, for example, what enabled the construction of the mosque over al-Mursì's grave in 706/1308, which was financed by one Zayn al-Dīn, who also paid for its muezzin, imam, and caretaker. ${ }^{39}$ It can thus be said that Alexandria's trend of Sufism not only flourished intellectually through the presence of spiritual authorities and their massive following, but also in terms of topography. Christian Décobert has contended

38 There were other ribāts in Alexandria as well, such as that of Abū 'Abd Allāh al-Așāiir, that of al-Jazūlī, which was in the city's wall near Kom el-Dikka, that of Ibn 'Abd Allāh alḤakkārī (d. 683/1284), and a khānqāh of Bìlīk al-Muhsinīi, founded by Sufis from the east, see: Décobert, "Alexandrie au xııı siècle," pp. 85-87, and Ibn Abī al-Manșūr, La risāla, p. 104b.

39 Ibn al-Ṣabbāgh, Durrat al-asrār, p. 157; for the date, see: Décobert, "Alexandrie au XıIIe siècle," p. 85 . 
that this development in the field of Sufism owed much to Alexandria's marginalization which, as we have seen, was due to its economic stagnation and the constant Frankish threat. This, he believes, allowed for the establishment of convents as autonomous religious enterprises that were able to play a significant role on a local level. There thus appears to have been a link between the city's administrative decline and the emergence of a new form of religiosity. In other words, Alexandria's shift away from being a city known for trade actually facilitated its transformation into a city known for piety. ${ }^{40}$

This milieu provided exceptionally fertile grounds for the Shādhiliyya with its Maghribi roots to lay the foundations that would enable it to grow into one of the most influential Sufi orders of Islamic history. It was naturally not hard for Alexandria's considerable population of Muslims of western origin to embrace the path of the Maghribi shaykh al-Shādhili and his Andalusi successor, al-Mursī, so that the Shādhiliyya easily incorporated the school of Abū Madyan, which since its establishment had taken a prominent place among the city's Sufis. ${ }^{41}$ From the middle of the seventh/thirteenth century onwards the Shādhili ța $\bar{t}^{i} f a$ spread rapidly across Egypt and beyond through the effort of its shaykhs, thus attracting spiritual seekers towards Alexandria from all over the Muslim world. At least until roughly the turn of the century, the time around which Tāj al-Dīn Ibn 'Ațầ' Allāh al-Iskandarì (d. 709/1309) started preaching the Shādhilī way from al-Azhar's pulpit in Cairo, Alexandria remained the homebase of the Shādhiliyya. ${ }^{42}$ The importance of Alexandria not only as a center of Sufism, but as the main center of the Shādhiliyya, is an important observation for us, as this may very well have played a decisive role in al-Wāsițìs choice to head for the maritime city. As the stronghold of the early Shādhilīs, it would not have been difficult for a seeker on the Sufi path to end up in their convent in the city's northern quarter. With that in mind, we now return to the account of his journey, which will tell us firsthand what he encountered among them.

\section{Enter the Shādhiliyya of Alexandria}

The somewhat concise section in al-Wāsiț̣is autobiography on the Shādhilī Sufis he accompanied may at first sight appear to reveal very little about their teachings and practices. It is nevertheless exactly in his brevity that we may distinguish what were, at least according to his observation, some of the

40 Décobert, "Alexandrie au xıIIe siècle," pp. 95-96.

41 Geoffroy, "Les milieux," p. 172.

42 Ibid. p. 178. 
prominent characteristics of Shādhilī doctrine as preached in Alexandria somewhere during the final fifteen years of the seventh/thirteenth century.

As has been done in chapter 1, we will again aim to historicize and expound upon al-Wāsițī's account through an in-depth study of other primary sources that make mention of the early Shādhiliyya. The most notable of these are listed below:

- The majority of the published works of Ibn 'Ațā' Allāh al-Iskandarī, the first shaykh to write books on Sufism according to the Shādhilī way. These are: his Kitāb al-hikam, a collection of spiritual aphorisms written before 686/1287, when al-Mursī was still alive; ${ }^{43}$ Kitāb al-tanwìr fì isqāt al-tadbìr, finished in 695/1296 according to Brockelmann, and perhaps his clearest elucidation of Shādhilī doctrine; ${ }^{44}$ Lațāaif al-minan fìmanāqib al-Shaykh Abì al-'Abbās al-Mursī wa-shaykhihi al-Shādhilì Abì al-Hasan, a biographical work concerned mostly with his own shaykh, al-Mursī, but also with alShādhilī. It must have been composed after Kitāb al-tanwìr, from which it quotes; ${ }^{45}$ 'Unwān al-tawfíq fi $\bar{a} d \bar{a} b$ al-țariq, a commentary on a poem about the Sufi way by Abū Madyan; Miftāḥ al-falāḥ wa-miṣbāḥ al-arwāḥ fì dhikr Allāh al-Karìm al-Fattāh, a small volume concerned with the remembrance of God; and al-Qașd al-mujarrad fi ma'rifat al-ism al-mufrad, about the divine names and attributes of God and their purpose in the spiritual way. I must point out that some scholars have doubted Ibn 'Ațā' Allāh's authorship of the latter two works. However, since I have found that both works have overlapping passages, and both appear to be consistent with his other writings, I see no reason to doubt their authenticity. ${ }^{46}$ Finally, there are also let-

43 According to Victor Danner, Ibn 'Ațāillāh's Ṣüfi Aphorisms (Kitāb al-Ḥikam) (Leiden: E.J. Brill, 1973), p. 15 .

44 Carl Brockelmann, Geschichte der arabischen litteratur (Leiden: Brill, 1996), vol. 2, p. 143.

45 Al-Iskandarī, Lațāif al-minan, p. 135.

46 For doubts concerning their authenticity, see for instance: al-Ziriklī, al-Alām, vol. 1, p. 222 (he only mentions Miftāh), and Hofer, The Popularisation of Sufism, p. 130-131. The latter's arguments are that both works contain no references to Ibn 'Ațā' Allāh's shaykhs, that they are not consistent with his style or the content of his other known writings, and that early biographies do not mention them. As for the first argument, Ibn 'Ațā' Allāh's Hikam also contains no references to his shaykhs but is known to be authentic. As for the second argument, it is striking that both al-Qașd and Miftăh have an almost identical description of the types of dhikr that can be done; compare al-Qașd al-mujarrad fi ma'rifat al-ism almufrad, ed. Khālid Muḥammad Khamīs (Cairo: Maktabat al-khānjī, 20o8), p. 72 with Miftāḥ al-falāḥ wa-mișbāḥ al-arwāh:fì dhikr Allāh al-karim al-fattāh, ed. Muhammad 'Abd al-Salām Ibrāhīm (Beirut: Dār al-kutub al-ilmiyya, 2005), pp. 30-33. Furthermore, there seems to be an overlap between al-Qașd, p. 46 and Lațäif al-minan, pp.137-138, and between al-Qașd, p. 48 and the Hikam, see: Ibn 'Ațä' Allāh (m. 709/1309) et la naissance de la confrérie šădilite / Ibn 'Ațā' Allāh (709/ı309) wa-nash'at al-țarīqa al-Shādhiliyya, ed. \& 
ters by Ibn 'Ațā' Allāh and by anonymous pupils of his which have been consulted.

- Kitāb Durrat al-asrār wa-tuhfat al-abrār by the Tunisian Shādhilī Sufi Muhammad b. Abī al-Qāsim Ibn al-Ṣabbāgh (d. 720/1320). After Ibn 'Ațā' Allāh's Lațāif al-minan, this is the earliest biography of al-Shādhilī. It also contains a chapter with sayings of other Shādhilī affiliates.

- Zinat al-nawāzir wa-tuhfat al-khawāțir by Jamāl al-Dīn Rāfic b. Muḥammad b. Shāfi al-Ṣumaydì (d. 718/1319). This is a collection of discourses that Rāfic heard directly from Ibn 'Ațā' Allāh during his classes on Sufism in Cairo. ${ }^{47}$

- I have also made abundant use of biographical dictionaries of the tabaqāt -genre, which need not all be mentioned here. Of particular importance have been three authors who were known to have been in contact with Shādhilī affiliates: 'Afîf al-Dīn 'Abd Allāh b. As'ad al-Yāfi'ì (d. 768/1367), whose profound respect for the Shādhiliyya is evident;"8 Sirāj al-Dīn 'Umar Ibn al-Mulaqqin (d. 804/1402), who was invested with the Shādhili Sufi cloak (khirqa) by Ibn 'Ațā̄ Allāh's brother, Sharaf al-Dīn Abū al-Barakāt Muhammad;49 and 'Abd al-Wahhāb al-Sha'rānī (d. 973/1565), who was sympathetic to the Shādhiliyya. ${ }^{50}$

In line with the structure of chapter 1, I have again identified three general themes to systematically study al-Wāsiți’s account. We will start by scrutinizing what can be said of the Shādhili țăiifa in al-Wāsițìs epoch in terms of its

trans. Paul Nwyia (Beirut: Dar El-Machreq Éditeurs, 199o), p. 129; and between Miftāh, p. 36 and Lată $i f$ al-minan, p. 114. As for the third argument, most early biographies do not give any titles. For instance, al-Subkī only names al-Tanwìr, cf. Țabaqat al-shäfíiyya, vol. 9, p. 23; al-Yāfici only names Lațāif al-minan and states that he has a number of other writings on the divine secrets, cf. Mir'āt, vol. 4, p. 185; and al-'Asqalānī only says that he has numerous writings (tașānīf 'adīda), without mention of any titles, cf. al-Durar al-kāmina, vol. 1, p. 324. Somewhat later biographies start to make mention of the first three titles I have mentioned above, e.g. al-Suyūțī, Husn al-muhāọara, vol. 1, p. 524, and 'Abd alWahhāb b. Aḥmad al-Sha'rānī, al-Ṭabaqāt al-kubrā, al-musamma: Lawāqị̣ al-anwār alqudsiyya fì manāqib al-'ulamā' wa-al-șüfiyya, ed. Aḥmad 'Abd al-Rahīm Sāyiḥ and Tawfīq 'Alī Wahba (Cairo: Maktabat al-thaqāfa al-dīniyya, 2005), vol. 2, p. 41. Examples of scholars who did consider al-Qașd and Miftāh authentic are Victor Danner, Ibn 'Ațāillāh's Ṣūfi Aphorisms, pp. 12-13, and Abū al-Wafā' al-Ghunaymī, Ibn 'Ațā' Allāh al-Sikandarī watașawwufuhu (Cairo: Maktabat al-anjlū al-mișriyya, 1969), pp. 107-111.

Jamāl al-Dīn Rāfi` b. Muḥammad b. Shāfi` al-Șumaydī, Zīnat al-nawāzir wa-tuhfat alkhawāṭir, ed. Yūsuf Aḥmad (Beirut: Kitāb nāshirūn, 2013), p. 31.

48 Al-Yāfi'ī repeatedly praises al-Shādhilī and his affiliates in his Mir'āt and refers to them as shaykhs whose status as friends of God is undisputed; see for instance: vol. 2, p. 13 where he calls al-Shādhilī a quṭtb, and vol. 3, p. 142 where he recognizes his friendship with God. This occurred in Alexandria, see: Sirāj al-Dīn Abū Ḥafṣ 'Umar Ibn al-Mulaqqin, Ṭabaqāt al-awliyā', ed. Nūr al-Dīn Sharībah (Cairo: Maktabat al-Khānjī, 1994), p. 5 o1.

As observed by Winter, Society and Religion, p. 72. 
network and formation as a distinct order; the second theme will be the Sufi doctrine that was prevalent among its followers; the final section will examine the success of the Shādhilīs and how this relates to the decision of our Iraqi Sufi to ultimately distance himself from them.

\subsection{The Network of the Early Shädhiliyya}

I have mentioned earlier that while the Rifāiiyya could already rightfully be called a Sufi order during al-Wāsițī's lifetime, it is not exactly clear when in the Egyptian Mamluk context Sufi groups became distinct orders, set up around the person and teachings of a particular shaykh. And even when we can clearly speak of a Sufi order proper, its exact moment of conception is in most cases difficult to ascertain, as the eponymous founder in all likelihood did not actually set it up himself. Rather, what became a Sufi order was likely construed by later followers who began to define the borders of their identity and behavior as a Sufi group, which they then traced back this eponymous shaykh. It is this gap in our understanding of medieval Sufism that has recently triggered Nathan Hofer to legitimately question what he calls the "institutionalization" of the early Shādhiliyya. ${ }^{51}$

Hofer argues that it is not until the early eight/fourteenth century that we find the first traces of al-Shādhilī's identity and method as the focal point for a group of Sufis to trace their authority back to. This, he holds, indicates that it must have taken nearly fifty years after the death of its eponymous founder before an actual institutionalized țāifa crystalized. ${ }^{52}$ He views Ibn 'Ațā' Allāh al-Iskandarì's hagiography Lațāif al-minan as a crucial basis from which Shādhilī Sufism as a distinct identity was construed:

By providing his readers with a narrative model for their devotions and doctrines, al-Iskandari formulated the contours of what it meant to follow al-Shādhilī and be a Shādhilī Sufi. Once a coherent model was in place, the subsequent formalisation of that model - what I call the 'institutionalised identity' of al-Shādhilī - became possible as Sufis began to narrate and embody the doctrines and practices implicit in the model. ${ }^{53}$

$5^{1} \quad$ Hofer, The Popularisation of Sufism, pp. 16-18, where he defines institutations as (1) social (generated and preserved through relations in a group); (2) normative (constraining and enabling the groups's behavior); (3) performative (the learned behaviours linked to a specific language of a group); (4) objective (for the group's members); and (5) dynamic (and thus subject to change).

$5^{2} \quad$ Ibid. pp. 111-112.

53 Ibid. p. 113 . 
By disseminating an idealized version of al-Shādhilī’s life, doctrine, and praxis, Ibn 'Ațầ' Allāh was, in a sense, the architect of this institutionalized Shādhilī identity. Hofer suspects that, in doing so, Ibn 'Ațā' Allāh simultaneously cemented his own career as the new leader of the Shādhili țăi ifa. He would thus have written Lațāif al-minan for two reasons: first, to legitimize the role of his own master, al-Mursī, as the spiritual successor to al-Shādhilī; and, second, to legitimize his own role as the spiritual successor of al-Mursī and spokesperson of the Shādhiliyya after him. ${ }^{54}$

The implication of Hofer's theory is that when al-Wāsiți entered a masterdisciple relationship of suhba under one of al-Mursì's students not long after 686/1287, he did not in fact become part of a distinct Sufi țāifa with its own distinct doctrine. Because, as we shall see, al-Wāsițī's autobiography gives the impression that this notion is incorrect, I have gone through the rich source material on the Shādhiliyya discussed above to see whether his account can be substantiated. The fruits of this labor are presented in the current section. I will argue that, at least in the final fifteen years of the seventh/thirteenth century, there was already a network of shaykhs that formed a distinct Sufi group, whose identity was inseparably linked to the person of al-Shādhilī via al-Mursī and which could justly be called a Sufi țāifa.

Al-Wāsiți makes it very clear that what he found in Alexandria was a țăiifa that identified itself with the name of Abū al-Hasan al-Shādhilī. When we return to where we left off in the previous chapter with the account of his journey, expressing his grief at the several disappointments he experienced in Iraq, he goes on to write: "But God (T) was kind to me, for I met a group $(t \vec{a} i f a)$ in Alexandria who recognized my goal and my search, so that I found a little bit of intimacy (ba'd al-uns) among them."55

Interestingly, his autobiography does not once state the name of this țāiffa, nor of any of its members. It could be that he did so out of reverence for them, and in particular for his own shaykh in the Shādhilī way, as his account does go on to denounce certain issues that he found problematic in their approach to Sufism. Perhaps he felt uncomfortable attaching the names of people he still greatly respected to his criticism. We can nevertheless be sure that he is referring to the Shādhiliyya when he speaks of this Alexandrian $t \bar{a}$ i ifa, not only thanks to Ibn Rajab's entry quoted at the beginning of the present chapter, but also because al-Wāsiți himself explicitly affirms that he was involved with them in two other works. After describing his time among the Baghdadi Sufis in his Q⿱äcida fí așnāf al-tảalluh, he says that he subsequently "turned to the

54 Ibid. pp. 113-114.

55 Al-Wāsițī, Rị̣la, pp. 33. 
way (tarīq) of the Shādhiliyya." ${ }^{\prime 6}$ And in a letter to one shaykh Ahmad alMaghribī we find him refuting the notion that a spiritual taste (dhawq) or unveiling (kashf) is by definition authentic, a view that was apparently upheld by the Shādhilīs: "I have only heard this statement or something similar to it from the group (ță $i f a)$ of the shaykh, the knower ('āriff), Abū al-Ḥasan al-Shādhilī."ñ

What can be said about this țāifa based on other primary sources? Granted, it is difficult to say much about the early Shādhiliyya, first, because there is hardly any material from its own adherents that predates the works of Ibn 'Ațâ' Allāh and, second, because biographical sources often make no mention at all of Sufi affiliation - and when they do, the information is often very meagre. The modern-day image of the early ța i ifa is that the line of its shaykhs started with al-Shādhilī, followed by al-Mursī, and that Ibn 'Ațā' Allāh was its third spiritual leader. This image neglects that while Ibn 'Ațā' Allāh certainly played a crucial role in the ța iifa as one of its most significant representatives in Cairo and the first of its shaykhs to compose works on Sufism, there were several other disciples of al-Mursī who were probably just as important in advertising the Shādhilī way. A noteworthy indication of this is found in a poem by al-Yāfi'i $\overline{1}$, wherein he eulogizes a hundred Sufi shaykhs and reserves several verses for Shādhilī affiliates. After praising al-Shādhilī and al-Mursī, he continues as follows:

Through [the guidance of al-Mursī] al-Iṣbahānī became the star (najm) of their ${ }^{58}$ sky,

And the moon of their guidance - their sword is a helper for those who possess little.

And esteemed was the servant Yāqūt, the ruby (yāqūt) around their neck,

By being firm upon the excellence of the spiritual way (sulūk).

And to Ibn 'Ațā' they granted the banner of divine friendship (wilāya),

And for illness [they granted him] a cure that dispels corruption

With which Dāwūd was treated, until this servant was cured,

And thus became a remedy for the calamity of disobedience.

And Marjānī, who was adorned with the pearls (marjān) of their ocean,

Dressed in garment embellished with the most splendid subtleties. ${ }^{59}$

56 Al-Wāsițī, Qā'ida fì aṣnāf al-ta’alluh, p. 151.

57 Al-Wāsițī, Risālatuhu ilā al-shaykh Ahmmad al-Maghribì, p. 110.

$5^{8}$ I have translated the suffix " $h \bar{a}$ " recurring throughout the quoted verses as "their." It must be noted that since al-Yāfici does not present us with the complete poem, it is not possible to establish what he is referring to. 
Composed by a scholar who was a contemporary to several of the masters who are named, this poem is significant in that it attests to the existence of a network of shaykhs who during their respective lifetimes must have all enjoyed a position of authority. It will be useful to have a closer look at their background, and to add several other figures who are mentioned in the sources as Shādhili affiliates in order to see what can be said about the way they were related to one another.

The first verse quoted from al-Yāfi'î's poem is clearly a reference to the person who was al-Wāsițī's own Shādhilī shaykh in Alexandria: the Persian Najm al-Dīn 'Abd Allāh b. Muḥammad al-Iṣbahānī (or Ișfahānī). ${ }^{60}$ The most important source on him is al-Yāfi'i $\overline{1}$, who had met him in Mecca and describes him as having been a handsome man with a long beard and an awe-inspiring appearance. ${ }^{61}$ Born in 643/1245 in current-day Iran, Najm al-Dīn probably lived in Shiraz for some time, where he accompanied a Sufi guide by the name of Abū 'Alī Barghash al-Shirāzī. ${ }^{62}$ It may have been this shaykh who told him to go to Egypt, where he would meet the spiritual axis $(q u t \underline{b})$ of his time. A hagiographic tale describes that Najm al-Dīn was captured by bandits (or Mongols, in another version) during his journey to Egypt, but was able to escape after he was freed by a shaykh who miraculously appeared to him when he recited a poem about his hazardous situation. Once Najm al-Dīn arrived in Alexandria and was directed towards al-Mursī by some of his followers, he discovered that it was in fact al-Mursī who had freed him from his captivity. ${ }^{63}$ From that moment on he remained a pupil of al-Mursī until his shaykh's passing in 686/1287. Several years before the turn of the century, Najm al-Dīn left Alexandria for good to spend the remainder of his life in Mecca, where he became the main representative of the Shādhiliyya. ${ }^{64} \mathrm{He}$ seems to have enjoyed some status there as

6o Al-Dhahabī, Tārîkh, vol. 48, p. 274, note that the editions of al-Dhahabìs Dhayl, p. 206 and al-Asqalānī's al-Durar al-Kämina, vol. 3, p. 86 both erroneously state that Najm al-Dīn accompanied (șaḥiba) al-Wāsițī.

$61 \quad$ Al-Yāfíī, Mir'àt, vol. 4, p. 198

62 Al-Ṣumaydī, Zìnat al-nawāzir, p. 107.

63 Al-Yāfi'ì, Mirāät, vol. 4, p. 198, and al-Iskandarī, Lațāìif al-minan, p. 69. Note that Ibn al-Ṣabbāgh relates a completely different story: he states that, in search of the quțb, Najm al-Dīn took a boat that broke down and was miraculously saved from the water by alMursī; see: Ibn al-Ṣabbāgh, Durrat al-asrār, p. 157.

64 Najm al-Dīn must already have been in Mecca several years before 699/1299, since that is the year Abū Muhammad al-Marjānī passed away in Tunis, and he is said to have met with him in the sanctuary, see: Ibn al-Ṣabbāgh, Durrat al-asrār, p. 157. See also: al-Ṣafadī, alWāfì, vol. 17, pp. 321-322; Al-Yāfi'ī, Mir'āt, vol. 4, p. 199; al-Iskandarī, Lațāìif al-minan, p. 68; al-'Asqalānī, al-Durar al-kamina, vol. 3, p. 86; al-Dhahabī, Tärīkh, vol. 48, p. 274; Ibn alMulaqqin, Țabaqāt al-awliyā', p. 459 . 
a spiritual master, as it is said that all the great shaykhs who arrived in the holy city would meet with him. ${ }^{65}$ Although the sources make no mention of him having had disciples, the fact that al-Wāsiṭi took him as his master suggests that he was already a full-fledged shaykh of tarbiya, able to teach the Sufi way well before he left Alexandria for the holy precinct.

The next verse in al-Yāfi'î’s poem refers to Yāqūt b. 'Abd Allāh al-Ḥabashī (d. 732/1331), who like Najm al-Dīn had been a disciple of al-Mursī. Very little is known of him, but it is certain that he became the foremost Shādhili shaykh in Alexandria after the passing of his master. He must therefore have had a considerable following, although few examples are mentioned in biographical literature. ${ }^{66}$ Among them we find Ḥasan (or Ḥusayn) al-Khabbāz (d. 791/1389) and Shams al-Dīn Muḥammad b. Aḥmad Ibn al-Labbān (d. 749/1348). It is not known whether these two disciples knew one another, but they certainly had several things in common. Both were Shāfi'is, both married one of Yāqūt's daughters, and both represented the Shādhiliyya in Cairo. The former, alKhabbāz, established a convent of his own in the city's vicinity and is mentioned as having invested disciples with the Shādhilī Sufi cloak (khirqa) on the authority of his shaykh, Yāqūt. ${ }^{67}$ The second disciple, the Shāfi' jurist Ibn alLabbān, reportedly taught the Shādhilī way from the Cairene Mosque of 'Amr b. al-'Ạ̦̣. ${ }^{6}$

The next two verses in al-Yāfi'î's poem are reserved for Ibn 'Ațā̄' Allāh and his most celebrated disciple, the Mālikī jurist Sharaf al-Dīn Dāwūd Ibn Bākhilā (or

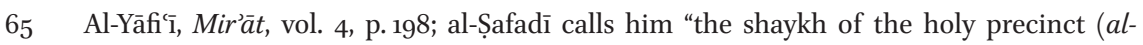
h̆aram)," cf. al-Wāfì, vol. 17, p. 321.

66 While Yāqūt is mentioned in many biographical dictionaries, the entries on him are all meager. Al-Dhahabī refers to him as "the renunciant of Alexandria (zāhid al-Iskandariyya)," cf. al-Dhahabī, al-Tbar, vol. 4, p. 93. His fame in Alexandria is also attested to by Ibn Bațțūta, who was initiated by him, cf, Rihla, vol. 1, p. 187. As for the entries on Yāqūt, see: Ibn al-Mulaqqin, Țabaqāat al-awliyā’, pp. 478-479; al-Yāfi'ì, Mir’āt, vol. 4, p. 213; Taqī al-Dīn Aḥmad b. 'Alī al-Maqrīīi, al-Sulūk li-ma'rifat duwal al-mulūk, ed. Muḥammad 'Abd al-Qādir 'Ațā (Beirut: Dār al-kutub al-'ilmiyya, 1997), vol. 3, pp. 161-162; al-Suyūṭī, Husn al-muhạậara, vol. 1, p. 525; Jamāl al-Dīn Yūsuf b. 'Abd Allāh Ibn Taghrī Birdī, al-Nujūm al-zāhira fì mulūk Mișr wa-al-Qāhira (Cairo: Wizārat al-thaqāfa wa-al-irshād al-qawmī, 1929-1938), vol. 9, p. 295.

67 Shams al-Dīn Muḥammad b. 'Abd al-Raḥmān al-Sakhāwī, al-Daw's al-lāmic li-ahl al-qarn al-tāsi' (Beirut: Dār maktabat al-ḥayāt, 1980), vol. 2, p. 5o. See also: Ibn Taghrī Birdī, alNujūm al-zāhira, vol. 11, p. 385; al-Maqrīzì, al-Sulūk, vol. 5, p. 271; al-Sha'rānī, al-Ṭabaqāt al-kubrā, vol. 2, p. 176.

68 Al-Subkī, Țabaqat al-shāfíiyya, vol. 8, pp. 94-96; al-Yāíīi, Mir'āt, vol. 4, p. 248; Taqī al-Dīn Abū Bakr b. Aḥmad Ibn Qāạī Shahba, Ṭabaqat al-shāfíiyya, ed. 'Abd al-'Alīm Khān (Beirut: 'Ālam al-kutub, 1986), vol. 3, pp. 52-54; Jamāl al-Dīn 'Abd al-Raḥmān b. al-Ḥasan al-Isnawī, Țabaqāt al-shāfíiyya, ed. Kamāl Yūsuf al-Ḥūt (Beirut: Dār al-kutub al-'ilmiyya, 2002), vol. 2, p. 194 . 
Mākhilā) al-Iskandarī (d. 733/1332). Ibn 'Ațā̄ Allāh, a native Alexandrian, had already migrated to Cairo while al-Mursī was still alive, and would eventually become the primary representative of the Shādhiliyya there. ${ }^{69}$ It is noteworthy that, according to al-Sha'rānī, Ibn 'Ațā' Allāh became the pupil (tilmìdh) of Yāqūt once al-Mursī had passed away, which suggests that it was Yāqūt who was considered the main shaykh of the tă iff after al-Mursī, and not Ibn 'Ațā' Allāh. ${ }^{70}$ It is likely that Ibn 'Ațā' Allāh traveled regularly through Egypt as both al-Shādhilī and al-Mursì had done before him, probably to spread the Shādhilī way and stay in touch with the several Shädhilī fractions that were stationed in other cities. He would surely have passed by Alexandria during such trips which, together with his correspondence via letters, preserved his link with the Shādhilī capital..$^{71}$ As Alexandrian disciples of al-Mursī, there is no doubt that Yāqūt, Ibn 'Ațầ' Allāh, and Najm al-Dīn knew one another. Ibn 'Ațā' Allāh viewed his two colleagues as knowers of God, and his own pupil, the aforementioned Rāfi', relates that both Yāqūt and Najm al-Dīn testified that Ibn 'Ațầ' Allāh is a quṭb. ${ }^{72}$ As for Ibn 'Ațā̄ Allāh's student Ibn Bākhilā, while his role as a shaykh in the țāifa remains unclear due to a scarcity of biographical information, we do know that he lived and died in Alexandria as a contemporary of Yāqūt. ${ }^{73}$

Most pupils of Ibn 'Ațā' Allāh would naturally have lived in Cairo, however. Noteworthy are two Cairene disciples who also appear to have been connected in some way to important Shādhilī figures of Alexandria. The first, Rāfí, would

69 Ibn 'Ațā' Allāh was already in Cairo in $684 / 1285$, as attested to by a poem he sent from there to Makīn al-Dīn al-Asmar in Alexandria, see: Tāj al-Dīn Aḥmad Ibn 'Ațā̄ Allāh alIskandarī, Min kalām sayyidī al-mușannif wa-inshādihi wa-qașā̉idihi, MS. Or. 329(2), Leiden University, fol. 68b.

70 Al-Sha'rānī, al-Ṭabaqāt al-kubrā, vol. 2, p. 41.

$71 \quad$ For Ibn 'Ațā̄a Allāh's correspondence with Alexandria, see his Tartīb al-sulūk, wa-yalīhā Risāla fì adab al-iilm, ed. Khālid Zahrī (Beirut: Dār al-kutub al-ilmiyya, 20o6), p. 45; see also footnote 69 . According to al-Ghunaymī, he sent the letter contained therein in 694/1295, cf. al-Ghunaymī, Ibn 'Ațā' Allāh, p. 101. For Ibn 'Ațā' Allāh's travels, see the letter by one of his pupils: Anon, Risāla li-ba'd fuqarā'sayyidī al-shaykh Tāj al-Dīn Ibn 'Ațā' Allāh radī Allāh 'anhu, MS. Or. 329(7b), Leiden University, fol. 94b-95a; here we find mention of Ibn 'Ațā' Allāh having travelled to Alexandria and Damiette in 707/1307. See also: alIskandarī, Lațäifi al-minan, p. 148, where we find that he met with Sultan al-Malik al-Manșūr Ḥussām al-Dīn Lājīn in Alexandria, which means that he must have visited the city before 698/1299, the year in which the sultan died.

72 Al-Iskandarī, Lațāiif al-minan, pp. 75-76, and al-Ṣumaydī, Zìnat al-nawāzir, p. 22.

73 Ibn al-Mulaqqin, Ṭabaqāt al-awliyā', pp. 517-518; Muhammad b. Muhammad Makhlūf, Shajarat al-nūr al-zakiyya fi țabaqāt al-Mālikiyya, ed. 'Abd al-Majīd Khayālī (Beirut: Dār al-kutub al-'ilmiyya, 2003), vol. 1, p. 293; al-'Asqalānī, al-Durar al-kāmina, vol. 2, p. 226;

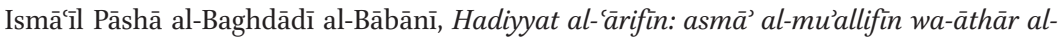
mușannifin (Istanbul: Wikālat al-Ma'ārif, 1951), vol. 1, pp. 36o-361. 
surely have entered the Shādhilī network when he studied Qur'anic recitation under the Shāfíi jurist Makīn al-Dīn al-Asmar al-Lakhmī (d. 692/1293), a direct disciple of al-Shādhilī. ${ }^{74}$ Although I found no mention of him having met Yāqūt or Najm al-Dīn, he was clearly aware of their position in the Shādhiliyya when he states about them that "there is no doubt about their friendship [with God] (wilāya) and the greatness of their rank (sha'n)."75 Besides Rāfi', we find that Ibn 'Ațā' Allāh's disciple Shihāb al-Dīn Abū al-'Abbās Aḥmad Ibn Maylaq (or Malyaq) (d. 749/1349) must have been in contact with shaykh Yāqūt as well. ${ }^{76}$

The final verse of al-Yāfi'î's poem refers to 'Abd Allāh Abū Muḥammad alMarjānī (d. 699/1299), a Mālikī jurist and Sufi shaykh who lived in Alexandria and Cairo and eventually moved to Tunis, where he passed away. ${ }^{77}$ The fact that Ibn 'Ațāa' Allāh and Ibn al-Ṣabbāgh both quote from him attests to his connection with the Shādhiliyya, although its exact nature remains unclear. ${ }^{78} \mathrm{Ibn}$ al-Ṣabbāgh relates that al-Marjānī met with Najm al-Dīn when he was in Mecca, which shows once more that there was contact between shaykhs who were in some way associated with the Shädhilī network, even if there was a considerable geographical distance between them.

There are a few other shaykhs not mentioned in the poem that deserve to be added to the current list for the sake of our knowledge of the Shādhili network. First is the son of al-Shādhilī, Shihāb al-Dīn Aḥmad Ibn Abī al-Ḥasan, who appears to have made a name for himself as a Shādhilī master in Alexandria. A letter that he wrote to a disciple of his in Giza, southwest of Cairo, proves that he had followers outside of Alexandria as well..$^{79}$ That he also had a bond with al-Mursī is affirmed in a poem by the latter in praise of Shihāb al-Dīn,

74 Al-Suyūṭī, Husn al-muhạậara, vol. 1, p. 507; see also: al-'Asqalānī, al-Durar al-kāmina, vol. 2, pp. 233-235.

75 Al-Ṣumaydī, Zinat al-nawāzir, p. 22.

76 Al-Sharrānī, al-Tabaqāt al-kubrāa, vol. 2, p. 176. On Ibn Maylaq, see: Ibn Taghrī Birdī, alNujūm al-zāhira, vol. 10, p. 242; al-Yāfi'ì, Mirāât, vol. 3, p. 250; al-Suyūṭī, Husn al-muhạậara, vol. 1, p. 552; al-'Asqalānī, al-Durar al-kāmina, vol. 5, p. 438.

77 Ibn al-Mulaqqin, Țabaqāt al-awlìyā', p. 441; al-Yāfi'ì, Mir'āt, vol. 4, pp. 174-175; Makhlūf, Shajarat al-nūr, vol. 1, p. 277; Șalaḥ al-Dīn Khalīl al-Ṣafadī, A'yān al-'așr wa-a'wān al-nașr, ed. 'Alī Abū Zayd et al (Beirut: Dār al-fikr al-mu'āșir/Damascus: Dār al-fikr, 1998), vol. 2, pp. 719-720.

78 Tāj al-Dīn Ahmad Ibn 'Ațā' Allāh al-Iskandarī, Kitāb al-tanwìr fì isqāt al-tadbīr (Beirut: Dār al-kutub al-ilmiyya, 6002), p. 82, and Ibn al-Sabbāgh, Durrat al-asrār, pp. 157, 162, 164, and 169 .

79 Shihāb al-Dīn Ahmmad b. 'Alī al-Shādhilī, Risālat Sayyidinā al-shaykh al-imām al-'ālim alārif Shihāb al-Dīn Ahmad, MS. Or. 329(7b), Leiden University, fol. 10oa. Ibn 'Ațā̄ Allāh appears to confirm his role as an independent shaykh in Lațäif al-minan, p. 54. 


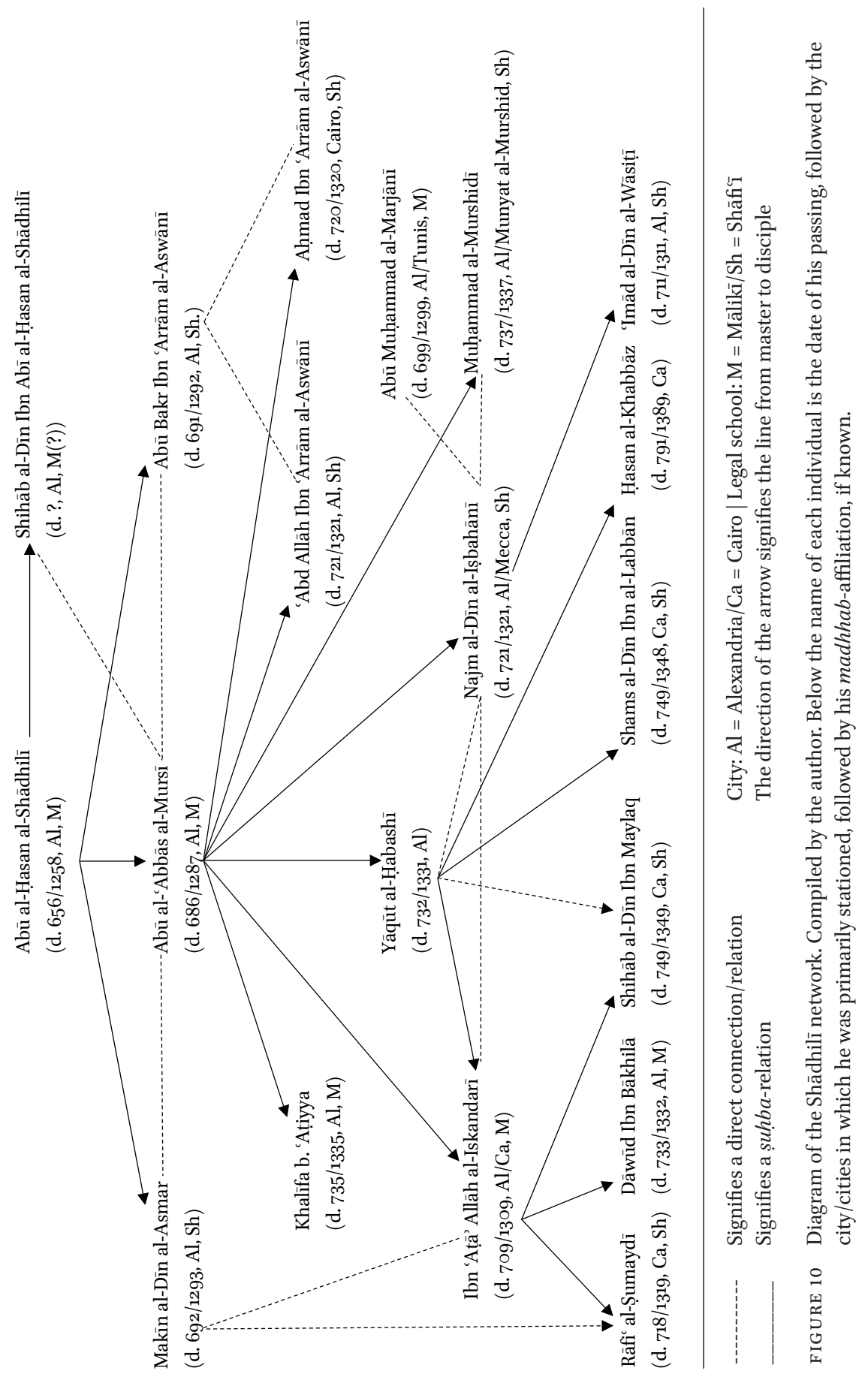


quoted by Ibn al-Ṣabbāgh. ${ }^{80}$ Furthermore, the Sufi shaykh Abū 'Abd Allāh Muhammad al-Murshidī (d. 737/1337) had been a disciple of al-Mursī and also seems to have known Najm al-Dīn. He eventually started his own convent east of Alexandria, in a village currently known as Munyat al-Murshid. ${ }^{81}$ The Alexandrian Shāfiī jurist Zakī al-Dīn Abū Bakr Ibn 'Arrām al-Aswānī (d. 691/1292) had been a disciple of al-Shādhilī and married one of his daughters. According to Ibn 'Ațā̄' Allāh's Lațāiif al-minan, he also personally knew al-Mursì. ${ }^{82}$ The fact that both his sons, Bahā' al-Dīn Aḥmad Ibn 'Arrām al-Aswānī (d. 720/1320) and 'Abd Allāh Ibn 'Arrām al-Aswānī (d. 721/1321), subsequently became disciples of al-Mursī may indicate that there was already an awareness of a Shādhilī 'Sufi genealogy' during their lifetimes. It can hardly be a coincidence that we have here two sons who followed the successor of their father's shaykh in tașawwuf..$^{83}$ Finally, we find that the otherwise unknown Māliki jurist Khalīfa Ibn 'Ațiyya (d. 735/1335) is mentioned as a disciple of al-Mursī, too. ${ }^{84}$

In spite of the several blanks in our picture of the network of Shādhili affiliates, the above enumeration enables us to make a diagram (as depicted on page 92) based on which several relevant observations can be made. First, almost all the individuals we have identified as affiliates of the Shādhiliyya were connected to each other by being part of the Shādhilī chain of șụ̣ba, which signifies their master-disciple relationship with one of the shaykhs in the $t \bar{a}$ iffa's network. Second, the diagram shows that there does not appear to have been one clear-cut leader of the Shādhiliyya after al-Mursī. Instead, we find that each city with a Shādhilī community could have one or even several local shaykhs, who each had disciples of their own. Alexandria in particular had several shaykhs who were apparently authorized to train their own pupils in the Shādhili way. This, of course, is not strange in view of the fact that the țầifa was rapidly gaining followers with the rise of its popularity, which is also reflected in the sudden shift away from Alexandria after the death of al-Mursī. Where the majority of the first and second generation Shādhilīs were, at least initially, naturally based in Alexandria, the home-base of al-Shādhilī and al-Mursī, it is seen that many of the $t \bar{a}$ i $i f a^{\prime}$ ' major figures of the generation after that were

\footnotetext{
8 I Ibn al-Sabbāgh, Durrat al-asrār, pp. 155-156.

81 Al-Yāfi'ī, Mir'āt, for al-Mursī being his shaykh: vol. 4, p. 221, for his connection to Najm alDīn: vol. 4, p. 198. See also: al-Suyūṭī, Husn al-muhậ̣̂ra, vol. 1, p. 525; al-Ṣafadī, al-Wāfĭ, vol. 3, pp. 294-295.

$82 \quad$ Al-Iskandarī, Lațāifi al-minan, pp. 65 and 84.

83 For Abū Bakr, see: Ibn al-Mulaqqin, Ṭabaqāt al-awliyā', p. 485; for Ahmad, see: al-Ṣafadī, al-Wāfĭ, vol. 6, p. 168, and Ibn al-Mulaqqin, Țabaqāt al-awliyā', p. 514; for 'Abd Allāh, see: al-Ṣafadī, al-Wäfì, vol. 17, p. 5 \%.

84 Ibn al-Mulaqqin, Țabaqāt al-awliyā', p. $55^{2}$.
} 
based in Cairo. Third, we have seen indications in our sources that several shaykhs of the generations after al-Mursī were in contact with each other, surely on the basis of their affiliation with the Shädhiliyya. There was correspondence via letters and some shaykhs would travel through Egypt to visit other Shādhilī fractions. Some of the affiliates, such as al-Marjānī and al-Murshidī, seemingly operated independently of the țâi ifa, but may have still maintained a connection of some sort with its shaykhs. Last but certainly not least, what is particularly striking is that the diagram shows very clearly that every chain of affiliates from al-Wāsițī's generation goes back exclusively to al-Mursī, who can thus be seen as the common link in the țâaifa. It is this final observation that will be of great significance to our further study of al-Wāsițîs account below.

We have thus far seen that al-Wāsiți obviously viewed the Shādhiliyya as a Sufi ța iffa. As such, I have tried to give an overview of what the network of this țäifa looked like based on other primary sources. While the observations we have thus far made provide some grounds to assume that there indeed existed a network of Shādhilī affiliates in Egypt and beyond that operated as a distinct Sufi group at the time of al-Wāsitị̂s initiation by Najm al-Dīn, the issue is not yet settled. It will therefore be useful to explore whether there existed something of a common Sufi doctrine within this network of shaykhs. If the teachings al-Wāsiți relates from Najm al-Dīn correspond to what is found in the earliest Shādhilī writings, most notably those of Ibn 'Ațầ' Allāh, this would be a strong indication that a distinct Sufi doctrine existed among the Shädhilīs, the common link of which would have been al-Mursī, in whom all lines of șuḥba come together. This would then mean that it is possible to locate the point at which the Shādhiliyya existed as a distinct Sufi țăi ifa as early as al-Mursī. I will come back to this in the conclusion to the section that now follows, in which we will examine what can be said about the teachings of the Shādhiliyya at the time of our Iraqi Sufi's stay in Alexandria.

\subsection{The Doctrine of the Early Shädhiliyya}

The difficulty with al-Wāsițīs description of the Shādhilīs in his autobiography is that it comes across in itself as an insignificant sequence of spiritual qualities he claims to have witnessed among them. It is only after careful consideration and comparison with other writings of al-Wāsiți that one will find that several passages actually contain references to the Sufi doctrine that he identified as characteristic of the țāiffa. He says, for instance:

One of them considers his own self-direction (tadbir) and choice (ikhti$y \bar{a} r)$ to be among the greatest sins, so that he happily welcomes his Lord's choice and trusts in it, relying on whatever his Lord has designated in His 
pre-eternity ( $f$ i azalihi) according to His divine wisdom and mercy. This comes to the point that it seems as if this one is in the presence of his Lord, seeing Him with the vision of his heart (yarāhu 'iyānan bi-qalbihi). The signs of [God's] majesty, love, and magnificence shine on his face and he submits to His decree $(h u k m)$. I found such signs among them and in their movements, their stillness, and the fluctuations of their hearts (taqallubät). ${ }^{85}$

As I have pointed out before, al-Wāsițīs autobiography makes no mention of names in the section on the Shādhiliyya. Nonetheless, we can almost be certain that the above quote is actually a direct description of Najm al-Dīn, his own Shādhilī mentor in Alexandria. In Q Qácida fì al-tajrìd he provides us with the only explicit reference to his shaykh's teachings that I have come across in his writings, and it clearly overlaps with the above quote:

Shaykh Najm al-Dīn - may God renew his blessing - told me some words that summarize the beginnings and the endings [of the spiritual way], which I only understood after fifteen years. I thus came to know that he never held back any good council from me. He said: "Your reflection on what has passed and your attempt to direct (tadbiruka) what is to come distract you from the state you are in at the moment (al-hâl fi al-waqt). This requires [that you] perfect piety $(\operatorname{taqw} \bar{a})$ in your inward being and become aware of your passing thoughts (khawātir) out of shame before God (T), which is the beginning of the path of those who are drawn near [to Him] (al-muqarrabin)."

He also told me something that comes down to the following: "God was and there was nothing with Him (kāna Allāh wa-mā shay'ma'ahu), so it is necessary for man that his heart becomes absent in the meaning [of these words]." 86

We find a very similar portrayal of Shādhilī teachings in al-Wāsițīs $Q \bar{a}$ cida fì așnāf al-ta'alluh, where he states that it is characteristic of the order to commence with the spiritual path by renouncing one's choice (ikhtiyār) and desire (irāda), and attaching oneself to al-Shādhilī: "Then will the ecstatic (wājid) find a spiritual taste (dhawq) through the divine attribute of antiquity (sifat al-qidam), since God was and there was nothing with Him, so that he is about to become veiled from all that is not [God] of created things." 87

85 Al-Wāsițī, Riḥla, p. 34.

86 Al-Wāsițī, Qā'ida fì al-tajrīd, p. 256

87 Al-Wāsițî, Qãcida fì aṣnāf al-ta’alluh, p. 151 . 
What is especially noticeable about the way al-Wāsițī summarizes Shādhilī doctrine in these citations is how it seems to be a very condensed form of several core teachings found in the earliest Shādhili writings, most notably those of Ibn 'Ațā' Allāh. It is, therefore, first and foremost through Ibn 'Ațā̄ Allāh that we can appreciate the true significance of al-Wāsițì's remarks here.

The first thing that we may recognize as a distinct aspect of Shādhilī doctrine is the stress that is laid on desisting from any claim to self-direction (tadbir), choice (ikhtiyār), or desire (iräda or shahwa), since it is ultimately God who controls all things. Now, it can be no coincidence that Ibn 'Ațā' Allāh starts his Hikam with several aphorisms that all deal with this in some way:

[1] One of the signs of relying on one's own deeds is the loss of hope when a downfall occurs.... [3] Preceding intentions cannot pierce the walls of predestined decrees (aqdār). [4] Free yourself from self-direction (tadbir), for that which Someone Else has carried out on your behalf you must not yourself undertake to do. [5] Your striving for what has already been guaranteed to you, and your neglectfulness of what is demanded of you, are a proof that your spiritual insight (bașira) is clouded. ${ }^{88}$

As the title indicates, this is also the main concern of Ibn 'Ațā' Allāh's Kitāb altanwīr $f i$ isqät al-tadbīr, which we may render as 'the Book of Illumination through the Elimination of Self-Direction.' In its introduction, Ibn 'Ațā' Allāh states that whoever seeks to arrive unto God (al-wușull ilä Allāh) must necessarily purify himself of having self-direction..$^{89}$ It is worthwhile noting that Ibn al-Ṣabbāgh and Ibn 'Ațā' Allāh relate very similar words from al-Shādhilī, the kernel of which is that living in this world with the assumption that you are the one directing your acts is one of the things that will cut you off from arrival (wuṣla). ${ }^{90}$ The gravity of this matter is such that Ibn 'Ațāa Allāh states in his Kitāb al-tanwìr that the truest miracle (karäma) of the friend of God is when he lives by tafwied, which is to entrust all affairs to God, since human beings cannot have any influence on the divine decree. ${ }^{91}$ Besides several other writings of Ibn 'Ațā' Allāh that expound such teachings, it appears from Rāfi's notes that he actively advocated this during his teaching sessions on Sufism as

88 I follow Nwyia's critical edition and numbering of the aphorisms; see: al-Iskandarī, $I b n$ 'Ațā' Allāh (m. 709/1309) et la naissance, pp. 84-85. I have relied on Danner, Ibn 'Ațāillāh's Süfi Aphorisms, pp. 23-24 for the translation, which I have slightly altered.

89 Al-Iskandarī, Kitāb al-tanwìr, p. 4.

9o Ibn al-Ṣabbāgh, Durrat al-asrār, p. 102; al-Iskandarī, Lațāiif al-minan, p. 135.

$91 \quad$ Al-Iskandarī, Kitāb al-tanwìr, p. 27. 
well. ${ }^{92}$ It is thus clear that it must have been an essential principle in the doctrine of the early Shādhiliyya to strive to eliminate one's self-direction, choice, and desire.

Although not completely straightforward, al-Wāsițī provides us with what appears to be the primary foundation on which this principle was built in his above-cited descriptions of Shādhilì doctrine. In all three of them we can find reference being made to God's pre-eternity, such as the words he says were taught to him by Najm al-Dīn: "God was and there was nothing with Him (kāna Allāh wa-mā shay'ma'ahu)." It is striking that these exact same words are found in the thirty-fourth aphorism of Ibn 'Ațā' Allāh's Hikam, which has added: “... and He is now as He was." ${ }^{93}$ This saying is actually based on a canonical hadīth that is found in al-Bukhārì's al-Jämi' al-șahịh, according to which the Prophet Muhammad said: "God was and there was nothing before Him..." 94 Its significance to the principle of rejecting one's self-direction and choice becomes clear from Ibn 'Ațā' Allāh's following explanation found in Kitāb al-tanwìr:

You should know that God was there for you before you were there for yourself. Now in the same way as He directed $\left(\right.$ mudabbir $\left.^{a n}\right)$ [your affairs] before you existed when there was nothing of your self-direction (tadbir) [to compete] with Him, thus He (ST) directs [your affairs] after you have come into existence. So be to Him as you were to Him [in pre-eternity], and He will be to you as He was to you [in pre-eternity]! ${ }^{95}$

Since God in the sovereignty of His lordship (rubūbiyya) has already directed all affairs in pre-eternity, the Sufi must fully grasp that creatures hold no power or control over anything and that they are all completely dependent on Him. ${ }^{96}$

92 See for instance al-Ṣumaydī, Zīnat al-nawāzir, pp. 252-256, 270, 444, 464, and 499. The significance of tadbīr and ikhtiyār in Rāfi's book was already noted by Denis Gril in his "L'enseignement d'Ibn 'Atâ' Allâh al-Iskandarî, d'après le témoignage de son disciple Râfi' Ibn Shâfi," in Une voie soufie dans le monde: la Shâdhiliyya, ed. Éric Geoffroy (Paris: Maisonneuve et Larose, 2005), pp. 98-99. For other references in Ibn 'Ațā̄' Allāh's writings, see his Tartīb al-sulūk, wa-yalīhā Risāla fì adab al-ilm, ed. Khālid Zahrī (Beirut: Dār alkutub al-'ilmiyya, 2006), p. 57, and his Lațäif al-minan, for example pp. 24 and 91.

93 Al-Iskandarī, Ibn 'Ațā' Allāh (m. 7og/ızog) et la naissance, p. 103.

94 Muhammad b. Ismāīil al-Bukhārī, al-Jāmi al-musnad al-șaḥ̄h al-mukhtașar min umūr Rasūl Allāh (șallā Allāh 'alayhi wa-sallam) wa-sunanihi wa-ayyāmihi, ed. Muhammad Zuhayr b. Nāṣir al-Nāṣir (Beirut: Dār țawq al-najāh, 2001), vol. 4, p. 105, and also vol. 9, p. 421.

95 Al-Iskandarī, Kitāb al-tanwìr, p. 14.

$96 \quad$ Ibid. p. 18. 
This principle revolves around the realization of an essential dichotomy between Lord ( $r a b b$ ) and servant ('abd), or between lordship (rubübiyya) and servitude ('ubūdiyya), which the early Shādhiliyya considered the way to reach the station of servitude (maquam al-ubüdiyya). Its prominence in their doctrine is reflected in the very definition of Sufism itself as attributed to alShādhilī by Ibn al-Ṣabbāgh: "Sufism is to train the carnal soul (nafs) to be in accordance with servitude, and to return it to the principles of lordship (ahkām al-rubübiyya). ${ }^{n 7}$ Several references to this dichotomy can be found in Ibn 'Ațā' Allāh's Hikam as well. In the 1ooth aphorism, for instance, he states that it is in carrying out one's servitude that the majesty of God's lordship manifests. ${ }^{98}$ In Kitāb al-tanwīr he explains that the Prophet Muhammad therefore chose servitude when he was made to choose between becoming a servant prophet (nabī 'abd) or a king prophet (nabì malik). For Ibn 'Ațầ' Allāh, this is also the definitive proof that servitude is the most noble of spiritual stations. ${ }^{99}$

Against this background we may understand what is implied by the earlierquoted statement al-Wāsițī related from one of the Shādhilīs (in all likelihood Najm al-Dīn himself) that self-direction and choice are among the greatest sins. Similar statements can in fact be found in several Shādhilī works. Ibn 'Ațầ' Allāh phrases it in almost identical words, and Rāfic attributes it to al-Shādhilī as follows: "Beware of self-direction and choice, for they are worse than offenses and sins." ${ }^{100}$ For the early Shādhilīs, the idea behind this notion is that if the servant lays claim to self-direction he is in fact competing with his Lord's decrees. He thereby makes himself an associate with God's lordship (shirk bial-rubūbiyya), which Ibn 'Ațā' Allāh also refers to as an inward form of idolatry. ${ }^{101}$ Therefore, according to the Shādhiliyya, it is only by cleansing the heart of attributing lordship to other things besides God that the servant becomes fit to be in His divine presence. ${ }^{102}$

Another seemingly distinct part of Shādhilī doctrine to which al-Wāsiți alludes three times in his autobiography is the role of God's divine names (asmä) and attributes (șifât). In his first mention of these terms he merely states that he found the Shādhilīs discussing experiential knowledge (márifa) of the

\footnotetext{
97 Ibn al-Ṣabbāgh, Durrat al-asrār, p. 90.

98 Al-Iskandarī, Ibn 'Ațā' Allāh (m. 709/1309) et la naissance, p. 129, and for the other references, pp. 121, 137, and 153 .

99 Al-Iskandarī, Kitāb al-tanwìr, p. 25 .

100 Ibn 'Ațā' Allāh makes a similar statement in Kitāb al-tanwīr, p. 27. For al-Shādhilī's quote, see: al-Ṣumaydī, Zīnat al-nawāzir, p. 287.

101 Al-Iskandarī, Kitāb al-tanwìr, pp. 11 and 13; al-Iskandarī, Lațāì al-minan, pp. 88-89 and 142.

Al-Iskandarī, Miftāḥ al-falāh, p. 37.
} 
divine names and attributes. The second instance provides some more detail and explains that "they enter the presence of the divine names (hadarät alasmä) and achieve spiritual realization (tahaqqaqū) through something from that. The reality of a divine name or attribute is granted to them and they thereby become intimately acquainted with God ('AJ)." 103 In the third instance, he describes that when they have emptied their hearts of all things other than God, they become filled with His love and the unveiling (kashf) of His names and attributes. ${ }^{104}$ While this suggests that the divine names and attributes fulfilled a role in the early țăiifa, al-Wāsițî̀s allusions do not fully convey their significance.

When we turn to Shādhilī sources, we find that their relevance to the spiritual way is a rather complex issue that will require some elaboration here. According to Ibn al-Ṣabbāgh, al-Shādhilī differentiated between the attributes of servitude, which belong solely to human beings, and the attributes of lordship, which belong solely to God. The Sufi must realize his own attributes while perceiving those of God. This principle can also be found in the 117th aphorism of the Hikam, which states: "Be connected to the attributes of His lordship and realize the attributes of your servitude." ${ }^{105}$ The aim is to thereby realize the nature of one's human attributes and their essential difference from God's divine attributes, a spiritual exercise which al-Shādhilī reportedly referred to as "sitting on the carpet of thruthfulness" (al-julūs 'alā bisāt al-ṣidq). ${ }^{106}$ For instance, the Sufi should realize that he is weak ( $d a$ ciff) while God is the Strong (al-qawiyy), that he is lowly (dhalīl) while God is the Almighty (al-aziz), that he is needy (faqïr) while God is the Self-Sufficient (al-ghanī). ${ }^{107}$ In other words, for the Shādhilīs it is through the divine names and attributes that one journeys deeper into the fundamental dichotomy of 'ubüdiyya and rubūbiyya.

The end of that journey, however, is a still deeper realization that people's existence as newly created, temporal beings is like non-existence in view of God's existence in pre-eternity. Ibn 'Ațầ' Allāh hints at this principle in a letter he sent to Alexandria, where he discusses whether it is better for the Sufi to be in a state of neediness (faqr) or a state of sufficiency (ghinā). He concludes that, ultimately, neediness is more perfect because it is an attribute of

\footnotetext{
103 Al-Wāsițī, Rị̣la, pp. 33-34.

104 Ibid. p. 34.

105 Al-Iskandarī, Ibn 'Ață' Allāh (m. 709/1309) et la naissance, p. 137, also hinted at in the 112th aphorism, p. 73 .

106 Ibn al-Ṣabbāgh, Durrat al-asrār, p. 72.

107 Ibid.
} 
servitude, whereas sufficiency is an attribute of lordship. ${ }^{108}$ The true meaning of neediness, he explains, only manifests by fully realizing God's pre-eternity:

The reality of neediness is to be after you have come into existence as you were before your existence, that is, just as [God] directed [your affairs] for you before your existence, without you having any saying in the matter. So be to Him as you were to Him, He will be to you as He was to you. Yet, the reality of neediness is only sound by being absent from it, for otherwise you will [still] be in a state of sufficiency by means of your neediness. ${ }^{109}$

The last sentence alludes to the station of annihilation $($ fan $\vec{a})$ wherein man's attributes become annihilated in God's attributes so that he loses awareness of all that pertains to the created realm. For awareness of one's own neediness would imply that a created, temporal attribute is still present together with the pre-eternal Creator. This process is also referred to in the 122th aphorism of the Hikam, where it is stated that "when [God] wants to make you arrive unto Him, He covers your attribute with His attribute and hides your quality with His quality." ${ }^{\prime 10}$ Ibn al-Ṣabbāgh quotes a like-minded statement from al-Shādhilī:

Just as your vile names can be obliterated by your excellent names, thus your [human] names can be obliterated through [God's] divine names, and your [human] attributes through His divine attributes, for nothing of the temporal being (al-hādith) will remain when he is connected to the Pre-Eternal (al-qadim).... When you call upon Him by His sublime name and pay heed to His sublime attributes existing in His essence, all of your names will be obliterated and your existence will have disappeared. You will have become effaced, having no existence whatsoever. This is the locus of annihilation, and of subsistence $\left(\right.$ baq $\left.\bar{a}^{\top}\right)$ after annihilation. ${ }^{111}$

That is not to say that a human being and God unite and become one, or that God incarnates in him. Ibn 'Ațā' Allāh clarifies that the servant can be adorned by God's names and attributes to the extent that it becomes conceivable that he is described by their good qualities and becomes "lordly" (rabbāniyy ${ }^{a n}$ )

\footnotetext{
108 Al-Iskandarī, Tartīb al-sulūk, p. 58.

109 Ibid. p. 57.

110 Al-Iskandarī, Ibn 'Ațā' Allāh (m. 709/1309) et la naissance, pp. 137-139. A similar saying is quoted from al-Mursī, cf. al-Iskandarī, Lațāîf al-minan, p. 26.

111 Ibn al-Ṣabbāgh, Durrat al-asrār, p. 132.
} 
- though not in the sense that he becomes like God, but rather that he is near to his Lord by his spiritual station (maqām).112

From being unconscious of the created realm in fanā', Shādhilī doctrine turns to the classical Junaydian model wherein perfection is only reached by returning to the creation with the profound consciousness that God is constantly governing it, perceiving that He is always manifest in all created things, which thence become as mirrors for His perfect attributes. ${ }^{113}$ This is the station referred to in the above quote of al-Shādhili as subsistence $\left(b a q \bar{a}^{3}\right)$, which is where the veil of self-direction is said to have fallen and the Sufi witnesses that everything is in the hands of God.114

There is one final aspect of Shādhili doctrine of which we can find hints in al-Wāsițī's autobiography. He characterizes the Shādhilīs twice by the word injidhāb to signify that they are drawn near unto God. ${ }^{115}$ In another passage he uses the word jadhb, which comes from the same Arabic root-letters. He says: "The spiritual states that [the Shādhilīs] have are penetrating, distinguished insights (muțālacatt) that cause the attraction of their spirits (jadhb al-arwāh $)$ unto the domains of divine proximity (mawātin al-qurb)."116 Now, al-Wāsițîs use of these terms is significant for us in view of the distinction that is made in several Shādhili sources between two ways to arrive unto God: that of the sâlik and that of the majdhüb. The former is the traveler on the spiritual path, who struggles through the necessary states and stations to earn his friendship with God. The latter reaches this status unintentionally when he is suddenly overtaken by spiritual attraction (jadhb) from God by which he is drawn unto Him. Rāfi' relates the following explanation of this distinction from Ibn 'Ațā' Allāh:

The likeness of the sălik is that of someone who digs for water, bit by bit, until he feels exhausted - but it is after exertion that it gushes forth to him. The likeness of the majdhüb is that of someone who desires water, and for whom a cloud [suddenly] rains so that he takes from it what he needs without any exertion. ${ }^{117}$

\footnotetext{
112 Tāj al-Dīn Aḥmad Ibn 'Ațā̄' Allāh al-Iskandarī, al-Qaṣd al-mujarrad fi márifat al-ism almufrad, ed. Khālid Muḥammad Khamīs (Cairo: Maktabat al-khānjī, 20o8), p. 48.

113 This process is elaborated upon in al-Iskandarī, Lațāif al-minan, pp. 30-31; God's manifestation in the creation is also mentioned in the $15^{\text {th }}$ aphorism, cf. Al-Iskandarī, Ibn 'Ațā' Allāh (m. 709/1309) et la naissance, p. 91.

114 Al-Iskandarī, Kitāb al-tanwìr, p. 55 .

115 Al-Wāsițī, Riḥla, pp. 33 and 49.

116 Ibid. p. 50.

117 Al-Ṣuwaydī, Zīnat al-nawāzir, p. 272.
} 
In Lațäif al-minan, both paths to God's friendship are said to be described in the Qur'an, with the verse "whoso makes God his friend (wa-man yatawalla Alläh)" [Q. 5:56] being interpreted as a reference to the sālik, and "He [God] takes care of the righteous (wa-huwa yatawallā al-șālihịn)" [Q. 7:196] being interpreted as a reference to the majdhūb. ${ }^{118}$ Ibn 'Ațā' Allāh maintains that the majdhūb has a higher degree of friendship with God because, contrary to the sălik, he achieves the station of arrival right away and then continues to abide by the precepts of the spiritual way. ${ }^{119}$

If we now return to the initial question posed in the preceding section, whether there already existed a distinct Shāhilī țăiifa when al-Wāsiți entered Alexandria, the above study provides solid ground to argue that this was very likely the case. We have seen that all the major characteristics by which our Iraqi Sufi describes the Alexandrian Shādhilīs can also be found expounded upon in early Shādhilī writings, most notably, but certainly not exclusively, those of Ibn 'Ațā' Allāh. While the fact that Ibn 'Ațā' Allāh was the first Shādhilī shaykh to compose books on Sufism ensured that his legacy as a master of the țâifa was preserved in history, this does not mean that its formation must therefore necessarily be placed with him. We must bear in mind that, originally, the teachings of the Shādhiliyya would primarily have been transmitted orally, which was likely a central aspect of the disciple's suhba-relationship with his Sufi master. Hence, it is related that when al-Shādhilī was asked why he never wrote any books, he responded that his pupils are his books, a principle al-Mursī is also said to have lived by ${ }^{120}$ Since we have noted that the common link between Najm al-Dīn (the source for al-Wāsițīs account of Shādhilī doctrine) and Ibn 'Ațā' Allāh was al-Mursī, we may then conclude that there was already a distinct doctrine and method that was transmitted orally within the latter's circle of disciples. Moreover, when we take into account that alMursī was the common link for the entire network of the Egyptian Shādhilīs that followed after him, the notion that a common doctrine existed among them that can be traced back to him becomes very plausible. All this, I would argue, points to the existence of a distinct țāifa well before the turn of the century, perhaps already under al-Mursī. I would even say that we should not disregard the possibility that it already originated under al-Shādhilī himself, although, admittedly, that will in all likelihood remain an unsolvable mystery.

118 Al-Iskandarī, Lațāi if al-minan, p. 27. Throughout the current study I have mostly relied on A.J. Arberry's translation of the Qur'an, though in several cases with slight alterations.

119 Ibid. p. 129.

120 Ibid. p. 6. 


\subsection{The Success of the Shädhiliyya}

Now that we have identified the Alexandrian Shādhilīs al-Wāsiți joined as a distinct Sufi țäifa with its own particular doctrine, we close his account of them with several observations that will explain to us, first, why he was initially attracted to their method in Sufism, and, second, why he eventually distanced himself from them. As with the Rifāiiyya, I will argue that his views on the Shādhiliyya can tell us something about the normative religiosity that dominated the context in which the țầifa thrived.

The first thing that is clear from al-Wāsițìs autobiography is that he had never seen Sufis like those of the Shädhiliyya before. In fact, of all the Sufi groups he accompanied during his lifetime, they were without a doubt the closest thing to what true Sufism should embody in his vision. He tells us in his autobiography: "By God, I felt intense joy with them and my heart found rest with them and their method (tariq), because I perceived with them something that is the highest degree that can be attained and the utmost limit that can be desired!"121 Moreover, one gets the impression from his choice of words that the Shādhilī shaykhs he met must have been highly charismatic figures. At one point, he even likens them to angels:

Truly - and God knows better the reality of the way I perceived them I likened them to the angels who are in the presence of God surrounding His Throne, even if they do not resemble them in every respect. Do not deem this strange, for their hearts are amidst the host of God's friends (awliy $\vec{a}$ ) surrounding the Throne, so that during most of their spiritual states their character $(t i b \bar{a})$ is transformed from that of a human being into that of an angel. This unique trait (khușussiyya) that they have cannot be denied and only they are able to achieve it. ${ }^{122}$

For al-Wāsițī, it must have been Najm al-Dīn in particular who inspired him, not just during his time in Alexandria, but also afterwards as he continued his journey in search of the pathway to God. He reveres him as a 'knower of God' (al-'ārif) in his autobiography, ${ }^{123}$ and concludes in his Q⿳亠丷⿵ ida fí al-tajrìd that

he (R) summarized for me everything that the seeker [of God] needs during the beginnings and the endings [of the spiritual way], such as vigilant awareness (murāqaba), experiential knowledge (márifa), annihilation 
(fana $)$, love (mahabba), and detachment (tajrid) - although I only understood this after a period of time. ${ }^{124}$

This shows that Najm al-Dīn had a considerable influence on his understanding of the Sufi path, a fact that we will be reminded of in part 2 of our study.

Al-Wāsițīs deep admiration for the Shādhiliyya was for the greater part grounded in what we may identify as the țāiffa's soberness, which manifested in its scholastic and practical approach to Sufism. It is in fact exactly on the basis of this soberness that several scholars have sought to explain the success of the early Shādhiliyya. Both Éric Geoffroy and Nathan Hofer view their sober Sufism as a product of the Malāmatī tradition, the Nishapuri way of blame, which emphasized the importance of keeping one's piety private. Moreover, Geoffroy contends that the Shādhiliyya was able to spread so quickly because its doctrine was formulated in words that were easily accessible to all kinds of people. He also argues that it was thanks to the "orthodoxy" of the early Shādhili masters that the țăiifa was easily accepted by Egypt's 'ulamă ${ }^{\prime}{ }^{125} \mathrm{~A}$ similar line of argumentation is adopted by Hofer, who states that the practical way of the Shādhiliyya created social space for many different strands of people to participate in Sufism. In his reading of Ibn 'Ațầ' Allāh's Lațāi if al-minan, he recognizes an effort to underline the Sunni credentials of the țāiffa's eponymous founder, al-Shādhilī, by constructing his image as a scholar and a jurist. ${ }^{126}$ He argues that, by doing so, Ibn 'Ațâ̄' Allāh aimed to secure the țẩifa's legitimacy within the domain of Sunni Islam - an approach we have also observed in the portrayal of al-Rifāi ì by his followers in the previous chapter. As we will now see, the sober character of the Shādhilīs is more or less confirmed by alWāsițī.

This is first and foremost illustrated by our Iraqi Sufi in terms of their close observance of Islamic law. In his autobiography he writes that he "found them the most strict of people in honoring the revealed law (sharita), the commands and prohibitions." 127 The scholastic background of the early Shādhilī masters is also attested to in several biographical sources. Al-Yāfici relates that besides Najm al-Dīn's knowledge of Sufism, he was also learned in Shāfiì jurispru-

\footnotetext{
124 Al-Wāsițī, Qā'ida fíal-tajrìd, p. 257.

125 Éric Geoffroy, "Entre ésotérisme et éxotérisme: les Shâdhilis, passeurs de sens (Égypte XIIIe - Xve siècles)," in Une voie soufie dans le monde: la Shâdhiliyya, ed. Éric Geoffroy (Paris: Maisonneuve et Larose, 2005), pp. 117-118. See also by the same author, Le Soufisme, pp. 490-491, where he argues that the order's balance between sharî́a and haqiqa was at the heart of its success.

126 Hofer, The Popularisation of Sufism, pp. 140-141 and 16o.

127 Al-Wāsițī, Rihlala, p. 34.
} 
dence. ${ }^{128}$ This may very well have played some role in his relationship with al-Wāsițī, who would himself still have followed the same madhhab when he was under his spiritual guidance. Furthermore, as we have already seen in the diagram above, practically all the notable members of the early țăiifa were to some degree trained in either the Mālikī or the Shāfiì school. Ibn al-Ṣabbāgh stresses that the close observance of religious law by following one of the legal schools was actually promoted by al-Shādhilī himself. ${ }^{129}$

With an approach to Sufism that aimed to be grounded in scholastic Islam, there are indications that early Shādhilī shaykhs may have occasionally been critical of Sufis who, in their eyes, did not sufficiently observe the boundaries of law and theology. A good example is the criticism towards the Rifāiiyya alWāsițī reports from Najm al-Dīn, who would have said that "nothing corrupts this religion like two groups: the Ahmadiyya when it comes to women and the Harīiyya when it comes to young boys." ${ }^{130}$ Although the evidence for an actual Shādhilī-Rifāî̀ rivalry is scarce, Geoffroy too has noticed that the two Sufi groups appear to have been quite incompatible and did not always go well together. ${ }^{131}$ According to Geoffroy, the critical attitude towards Sufis who were in some way regarded as transgressing the proper bounds of religious law can be viewed as characteristic of the early Shādhiliyya and was continued by later generations. ${ }^{132}$

Here we must make make note that some of the later Shādhilī shaykhs took a somewhat new direction that al-Wāsițī would not have been appreciative of. I am referring here to the growing influence of what many scholars have labelled 'the Akbarian school of Sufism,' which appears to have entered the Shādhili ța $\bar{a}^{i} f a$ somewhere after the turn of the seventh/thirteenth century. ${ }^{133}$

128 According to al-Yāfi'ì, Najm al-Dīn occupied himself with many religious sciences ('ulūm) and his book in jurisprudence (figh) was al-Ghazāli’s Wajizz, see: Mir'āt, vol. 4, p. 198; see also: al-'Asqalānī, al-Durar al-kāmina, vol. 3, p. 86.

129 Ibn al-Șabbāgh, Durrat al-asrār, p. 34.

130 Al-Wāsițî, Rihla, p. 24. The Ahmadiyya is, as noted in the previous chapter, one of the

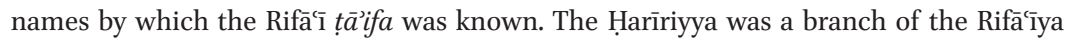
from Damascus, founded by 'Alī b. Abī al-Hasan al-Harīī al-Marwarī (d. 645/1147), cf. Louis Massignon, "Harīî̀ya," in $E I^{2}$ : vol. 3, p. 222.

131 Geoffroy gives an example in Le Soufisme, pp. 278-279, and also in "Les milieux," pp. 175176 .

132 Geoffroy, Le Soufisme, p. 178.

133 This trend among the Shādhiliyya has been studied in some detail by Geoffroy in "Entre ésotérisme," pp. 125-128 and Le Soufisme, pp. 221-222 and 391-392. He observes the increasing influence of Sufis such as Ibn 'Arabī, Ibn al-Fārị̣, and Ibn Sab'īn from the end of the seventh/thirteenth century onwards, and concludes that the Shādhiliyya played an important role in helping the advocates of ' $w a h d a$ ' rise from all-round denial to relative acceptance. He contends that it were in fact Shādhilī shaykhs who became the foremost 
Branded by its opponents as 'monists' (ittihādiyya), the Akbarian school is mostly known for the unity of being/existence (wahdat al-wujüd). It is closely connected to the doctrine of Muhyī al-Dīn Ibn 'Arabī (d. 638/1240), famously known as 'al-shaykh al-akbar' (the greatest master) from which the school derives its name. The latter's teachings were spread and expounded upon by his followers, such as his foremost disciple Șadr al-Dīn al-Qūnawī (d. 673/1274), and the latter's pupil 'Afîf al-Dīn al-Tilimsānī (d. 69o/1291). These figures and several others were increasingly incorporated by later Shādhilīs, a development that may have instigated some debate surrounding the legitimacy of the Shādhili țầifa in view of what some considered as its apparent incorporation of monistic teachings. I do not doubt that this, at least partially, motivated the Egyptian polymath and Shādhilī Suf Jalāl al-Dīn al-Suyūṭi (d. 911/1505) to prove that the early Shädhilī masters had nothing to do with the doctrine of divine indwelling (hulül) and unification (ittihāad). ${ }^{134}$ It is worthwhile noting that both he and Ibn Taymiyya relate a severe condemnation aimed at monistic Sufis that is attributed to al-Mursī, who would have held that "they are unbelievers ( $k u f f a r r)$, because they believe that the creation is the same as the Creator."135 In Ibn Taymiyya's version, this remark is even supposed to have been directed

interpreters of Ibn 'Arabī and Ibn al-Fāriḍ. Richard McGregor studied the considerable influence of Akbarian Sufism on the Wafā’iyya, a Cairene branch of the Shādhiliyya started by Muhammad Wafā’ (d. 765/1363), a disciple of Ibn Bākhilā, cf. "Akbarian Thought in a Branch of the Shâdhiliyya," in Une voie soufie dans le monde: la Shâdhiliyya, ed. Éric Geoffroy (Paris: Maisonneuve et Larose, 2005), pp.107-115. Ibn 'Arabī himself never formed a distinct madhhab or order, but, as Chittick explains, scholars have used the term "school of Ibn 'Arabī", "to refer to the fact that many Muslim thinkers ... took seriously Ibn 'Arabỉ's title as the "Greatest Master" (al-shaykh al-akbar) and consciously rooted their perspective in their own understanding of his theoretical framework." Cf. William C. Chittick, "The school of Ibn 'Arabî," in History of Islamic Philosophy: Part 1, ed. Seyyed Hossein Nasr \& Oliver Leaman (London/New York: Routledge, 1996), p. 510. It must be noted that some scholars appear to have also regarded those Sufis with monistic tendencies as being part of the Akbarian school, even though they may not have had any concrete relation with Ibn 'Arabī's thought. The poet Ibn al-Fārị, for instance, was a contemporary of Ibn 'Arabī who certainly did not belong to his circle, but whose poetry was so popular among Ibn 'Arabī's followers that he was in that sense incorporated into the Akbarian school by both its followers and its detractors, cf. Homerin, "Sufis and their Detractors," pp. 228-229.

134 Jalāl al-Dīn 'Abd al-Raḥmān b. Abī Bakr al-Suyūṭī, Ta’yìd al-ḥaqīqa al-'aliyya wa-tashyìd al-țarīqa al-Shādhiliyya, ed. 'Āṣim Ibrāhīm al-Kayyālī (Beirut: Dār al-kutub al'ilmiyya, 20o6), pp. 54-55; note that al al-Suyūṭī also defended Ibn 'Arabī against such criticisms. Jalāl al-Dīn 'Abd al-Raḥmān b. Abī Bakr al-Suyūṭì, al-Hāwī li-al-fatāwā (Beirut: Dār al-Fikr, 2004) vol. 2, p. 162, and Ibn Taymiyya's Haqüqat maddhab al-ittihādiyyīn, MF, vol. 2, p. 245. I believe al-Suyūtī actually cites from this work by Ibn Taymiyya, although he does not give the same title. 
specifically at the Akbarian master al-Tilimsānī and his following. As for alWāsițīs account, since his autobiography tells us that he was only introduced to the Akbarian school (which he termed 'al-ittihädiyya') in Cairo, we can assume that he found no evident traces of its doctrine when he was in Alexandria. That there was indeed a distance between the early Shādhiliyya and the followers of Ibn 'Arabī was also the impression of the late scholar of Sufism Paul Nwyia, who based himself on Ibn 'Ațā' Allāh's writings. ${ }^{136}$ We can thus say that, in all likelihood, distinct Akbarian teachings were still completely absent from the țăiifa as al-Wāsițī witnessed it, and were in all likelihood introduced only after Ibn 'Ațā' Allāh’s time.

Besides its scholastic and critical character, the Sufism of the Shādhiliyya must have also appealed to al-Wāsițī on a practical level. As several scholars have already noted, early Shādhilī shaykhs did not demand of their pupils that they wear a particular dress. This contrasted with many other Sufi groups in Alexandria, especially those with roots in the west, such as the followers of Abū Madyan, who wore the so-called patched Sufi cloak (muraqqa'a) to exhibit their renunciant lifestyle. ${ }^{137}$ Many such groups would also hold $s a m \bar{a}^{c}$ gatherings, a practice that was not undisputed among Muslim jurists as we have seen in chapter $1 .{ }^{138}$ This, too, was not done by the early Shādhiliyya, as attested to not only by the fact that al-Wāsiți makes no mention of it in his

${ }_{136}$ See Nwyia's introduction in: al-Iskandarī, Ibn 'Ațā' Allāh (m. 709/1309) et la naissance, pp. 25-26; I owe this reference to Alexander Knysh, Ibn 'Arabi in the Later Islamic Tradition: The Making of a Polemical Image in Medieval Islam (Albany: State University of New York Press, 1999), pp. 8o-81.

137 Ibn 'Ațā' Allāh states that the Shādhilī way does not promote renunciant clothing because that would draw attention to oneself and give the impression that one is in need of people's donations, whereas the Sufi should only be in need of God, cf. al-Iskandarī, Lațāi if al-minan, p. 134. The wearing of patched cloaks appears to have been practiced in the school of Abū Madyan, proof for which is found in Vincent J. Cornell, The Way of Abu Madyan: Doctrinal and Poetic Works of Abū Madyan Shu'ayb ibn al-Husayn al-Anșārī (c. 509/1115-16-594/1198) (Cambridge: Islamic Texts Society, 1996), pp. 96-67, and al-Tādilī, alTashawwuf, p. 439, where we find that the followers of al-Māghirī wore them.

${ }_{13} 8$ The Rifācī shaykh Abū al-Fath al-Wāsițī would certainly have organized samă $\bar{a}^{c}$ gatherings, given the importance of the ritual in his ță ifa. It is related that the Sufi master al-Shātịi practiced $\operatorname{sam} \bar{a}$, as this was the way of his own master, Abū al-'Abbās al-Ra's, cf. Ibn Abī al-Manșūr, La risāla, p. 108. The sama $\bar{a}^{c}$ was likely also performed in the Alexandrian community of Sufis with origins in the west, since we find that it was part of Abū Madyan's method, although with some caution, as noted by Cornell, The Way of Abū Madyan, pp. 34-35. It must be mentioned that not all Sufis from the west were in favor of the ritual, an example of which is Ibn 'Arabī, who hailed from Murcia, cf. William C. Chittick, The Self-Disclosure of God: Principles of Ibn al-Arabi's Cosmology (Albany: State University of New York Press, 1998), p. 383, and also: Claude Addas, Quest for the Red Sulphur: The life of Ibn 'Arabī, trans. Peter Kingsley (Cambridge: Islamic Texts Society, 1993), pp. 163 and 272. 
account of the țāiffa, but also explicitly by several Shādhilī sources. Both Ibn al-Ṣabbāgh and Ibn 'Ațā' Allāh relate that samā' was not done by al-Shādhilī, and al-Suyūṭi also confirms that it was not part of his method (tarīq). ${ }^{139}$ And thanks to Rāfi 'we know that it had still not integrated into the Shādhilī method of Sufism under Ibn 'Ațā̄' Allāh, who is cited on the issue as follows:

It is not proper for you to attend the sama $\bar{a}$ in this age. That is because the $s a m \bar{a}^{c}$ of the early [Sufis] was done to give rest to their spirits (nufüs), since the process of spiritual disciplining $(a l-r i y \bar{a} d a)$ is a fire that is extinguished through the $s a m \bar{a}$. But the folk of this age attend the $s a m \bar{a}^{c}$ because they're sick from eating too much food and being overly satiated, so that [the sama] strengthens their worldly desire. Sometimes, their carnal souls and desires are also stimulated because they listen to a beautiful voice. Now if you would say that al-Junayd, Sarrī, and others like them attended the $\operatorname{sam} \bar{a}$, then we would say to you: Indeed, but they would eat food and subsequently fast, whereas you will eat and not fast. ${ }^{140}$

Finally, the Shādhilī way was also sober in that it did not require from its followers that they renounce the world and live in poverty. On the contrary, the order's second shaykh, al-Mursī, is quoted as having emphasized the importance of having a means of subsistence (sabab), and Ibn 'Ațā' Allāh's Kitāb altanwir contains several passages that elucidate how the practice of Sufism can be combined with making one's daily livelihood. ${ }^{141}$

In view of al-Wāsițî's critical attitude towards what he perceived as a lack of regard for religious law among many Sufis and the acceptance of innovated rituals such as sama $\bar{a}^{c}$ gatherings, his stay among the Alexandrian Shādhiliyya must have seemed as if he had finally reached the destination of his journey, if only for a time. The way he explains it himself, he eventually traded Alexandria for Cairo because he became increasingly dissatisfied with his newfound Sufi companions for two particular reasons.

One of these may be identified as the first clear-cut instance where he displays his conviction that the traditionalist creed is the only correct creed. Although we have seen in chapter 1 that he appears to have denounced Ash'arism in favor of traditionalism in Baghdad already, it is only in the conclusion to his account of Alexandria that we find it formulated unambiguously for the first

139 Ibn al-Ṣabbāgh, Durrat al-asrār, p. 104; al-Iskandarī, Lațā̉if al-minan, p. 61; al-Suyūțī, Ta’yid, p. 73 .

140 Al-Ṣumaydī, Zīnat al-nawāzir, pp. 284-285.

141 Al-Iskandarī, Lațāiif al-minan, p. 97; and by the same author, Kitāb al-tanwìr, pp. 51-55 and 6o-117. 
time. While we should be open to the possibility that his theological criticism of the Shādhiliyya was formulated only later on during his Damascene years, he ascribes it such a central role in his autobiographical writings that it may very well reflect what had been his true sentiment. The Rihla describes his theological disagreement with the Alexandrian Sufis as one of the primary reasons behind his departure from them:

Then I thoroughly examined the foundation of this uppermost level (dhirwa) that [the Shādhilīs] have, in order to see on what it is based in terms of the articles and principles of faith (al-'aqā'id wa-al-ușūl). I found them to be a people who are not conscious of the Sunna, nor the era of the Prophet, the lives of his Companions, or [their] morality (akhlāq). I also found that they believe in something of the tenets of the Jahmiyya (lit. tajahhum); and although I did not find them openly declaring beliefs that strip God of His attributes $(t a t i \bar{l})$, they are nevertheless inclined to refrain from judgment [about them] (wuqūf). Indeed, I do not doubt that they deny some of the divine attributes (șifät), or refrain from judgment aboutthem, asistheschoolofthespeculativetheologians(mutakallimin).$^{142}$ Because of that I found that they are overshadowed by a darkness and that there is a disease in the lights of their faces. ${ }^{143}$

His claim of having detected elements of the Jahmiyya among his Alexandrian shaykhs is a common ploy used by traditionalists to equate followers of the Ash'arī school with a doctrine that is widely regarded as heretical among the majority of Sunni scholars, including the Ash'arīs themselves. ${ }^{144}$ He takes it a

142 The use of the term ' $w u q u \bar{f}$ ' in the context of theology is explained by Ibn Taymiyya in his al-Fatwā al-hamawiyya al-kubrā as follows: He differentiates between two groups who both differ in the way that they abide by the principle of wuqū f with regard to God's divine names and attributes: (1) A group that consists mostly of jurists ( $\left.f u q a h \bar{a}^{3}\right)$, who are said to profess that it is possible that the apparent (zähir) meaning is intended by any particular attribute of God in a way that befits His loftiness (jaläl), while remaining open to the possibility of it not being intended as such. (2) The second group are the speculative theologians who are said to profess that they refrain (yamsikün) from all of this, and do not go beyond the recitation (tilāwa) of the Qur'an or the reading (qiräa) of the hadith, thus turning away from their meanings with heart and tongue, cf. Ibn Taymiyya, MF. vol. 5, pp. 116-117. Al-Wāsițī, Rị̣la, p. 35 .

144 Ibn Taymiyya does this quite often; see for instance his Bayān talbīs al-Jahmiyya fì ta'sīs bida ihim al-kalāmiyya, ed. Yahyā b. Muhammad al-Hunaydī et al (Riyad: Majma' al-malik Fahd, 2005), vol. 1, p. 8, where he states that the Bayān talbīs is a refutation of the Ash'arī theologian Fakhr al-Dīn al-Rāzī, whom he refers to as one of the pseudo-Jahmī theologians (al-mutajahhima al-mutakallimin). 
step further in his Q $\bar{a}^{\prime} i d a f ı$ al-tajrìd, where he seems to be implying that Ash'arī kalām was an integral part of Shādhilī doctrine. After citing the earlier advice of Najm al-Dīn regarding the need to become absent in the meaning of the words "God was and there was nothing with Him," which we have identified as a reference to God's pre-eternity, al-Wāsițī remarks:

This is the key to intimate knowledge (ma'rifa) of God and knowledge of His existence according to the method of the speculative theologians (ahl al-kaläm). However, according to the method of the Ahl al-Sunna, the key to intimate knowledge is knowledge of God's aboveness (fawqiyya) in a way that befits His majesty, and not in a way that it is taken as one of the attributes of created beings. ${ }^{145}$

That is, in al-Wāsițīs vision of Sufism, the sound way to become intimately acquainted with God is built on the affirmation that He is above His creation, in accordance with the traditionalists (referred to here as the Ahl al-Sunna), whereas the way of the Shādhilīs is built on a deep realization of God's preeternity, in accordance with the Ash'arī kalām-scholars.

There are two important claims made by al-Wāsițī here: first, that the issue of pre-eternity is particular to the mutakallimūn (by which he undoubtedly means the adherents of the Ash'ari school); second, that there was a distinct presence of Ash'arī kalām in the early Shādhiliyya. Based on other primary sources, we can find that both claims actually have a historical basis.

Regarding the centrality of God's pre-eternity, there are many examples of works by followers of the Ash'arī school where we find mention being made of the notion that God existed in pre-eternity and that "He is now as He was." One of the earliest instances is found in the epistle on Sufism (al-Risāla) by the Asháaī Sufi al-Qushayrī (d. 465/1072), in a citation from Abū Bakr Muḥammad Ibn Fürak (d. 330/941), his teacher in theology and one of the early leading Ash'arī theologians. ${ }^{146}$ Other examples of important Ash'arīs who refer to this in their creeds are al-Ghazālī and 'Izz al-Dīn Ibn 'Abd al-Salām (d. 66o/1261).147

145 Al-Wāsițī, Qā'ida fì al-tajrìd, p. 256.

146 Abū al-Qāsim 'Abd al-Karīm b. Hūzān al-Qushayrī, al-Risāla al-Qushayriyya, ed. 'Abd al-Ḥalīm Maḥmūd \& Maḥmūd b. al-Sharīf (Cairo: Dār al-Ma'ārif, 1995), vol. 1, pp. 24-25. I owe this reference to Gibril Fouad Haddad's The Refutation of Him [Ibn Taymiyya] Who Attributes Direction to Allāh (al-Raddu 'alā Man Qāla bil-Jiha) (Birmingham: AQQSA Publications, 2008), p. 165-169.

147 For the former see: Abū Ḥāmid Muhammad b. Muḥammad al-Ghazālī, Ihyyā' 'ulūm al-dìn (Beirut: Dār al-ma'rifa, 2011), vol. 1, p. 9o. See also: al-Subkī, Ṭabaqāt al-shāfíiyya, vol. 6, p. 232. For the latter, see: 'Izz al-Dīn Ibn 'Abd al-Salām 'Abd al-'Azīz al-Sulamī, "Al-Mulha fì i'tiqād ahl al-ḥaqq," in Rasā̄il fı al-tawhìd, ed. Iyād Khālid al-Ṭabbā' (Beirut: Dār al-fikr 
It is also explicitly formulated as the creedal position of Ibn Taymiyya's contemporary and Asharī opponent, the qạ ḍ̄ Ahmmad Ibn Jahbal al-Kilābì (d. 733/1333). Upon mentioning God's pre-eternity, he writes: "He was without place - He created place and regulated time - and He is now as He was: this is the school (madhhab) of the Ahl al-Sunna and the creed of the shaykhs of the spiritual path (mashäyikh al-tarīq)."148 It is surely no coincidence that, just as we have found al-Wāsițī do above, Ibn Taymiyya too connects this phrase to the theology of the Jahmiyya. He is surely addressing the Ash'arīs when discussing words very similar to those we have just quoted from Ibn Jahbal:

Such words were spoken by some of the later Jahmī speculative theologians, and this was subsequently learned from them by those who reached the extremity of the tenets of the Jahmiyya (al-tajahhum) which is stripping God of His attributes $\left(t^{t} t \underline{t} l\right)$ and apostacy - although the former would say: "God was, without place and without time, and $\mathrm{He}$ is now as He was," while the latter say: "God was and there was nothing with Him, and He is now as He was."149

Ibn Taymiyya then goes on to explain the importance of this phrase in view of the kalämi argument against the literal interpretation of several attributes by which God describes Himself in the holy texts, such as His sitting (istiwā) on the Throne and His descent (nuzūl) to the lowest sphere of the heavens. He comments on this, saying that "[the Ash'arīs] maintain that [God] was not sitting on the Throne in pre-eternity $(a l-a z a l)$; and since He is now as He was, $\mathrm{He}$ will not be upon the Throne [in a literal sense], for that would require [that He underwent] something of a transformation and change."150 This shows that the issue of pre-eternity was of particular importance to the Ash'arī argumentation that God exists beyond time and space, so that the literal value of statements describing Him sitting on a Throne or existing in aboveness cannot possibly be affirmed. ${ }^{151}$

al-mucāṣir/Damascus: Dār al-fikr, 1995), p. 11. See also: al-Subkī, Ṭabaqāt al-shāfíiyya, vol. 8, p. 219.

148 al-Subkī, Țabaqāt al-shāfíiyya, vol. 9, p. 41. Also translated in Haddad, The Refutation, p. 165 .

149 Ibn Taymiyya, Haqüqat maddhab al-ittihāäiyyīn, $M F$, vol. 2, p. 272.

150 Ibid. vol. 2, p. 273 .

151 That is not to say that Ibn Taymiyya, or traditionalists in general for that matter, dismissed God's pre-eternity. The issue here is rather to show that the Ash`arī and Shādhilī use of the notion as identified by al-Wāsițī can indeed be verified as a historical reality. For further notice of the importance of God's eternity in Ash'arī theology, see also: Michel Allard, Le 
As for the distinct presence of Ash'arism in the early Shādhilī way of Sufism, this is exemplified most clearly when we look at Izālat al-shubuhät 'an al-āyāt wa-al-ahāàith al-mutashābihāt, a treatise by Yāqūt's pupil Ibn al-Labbān. Its aim is to refute what he labels the literalism of the traditionalists, whom he accuses of ascribing anthropomorphism (tashbih $)$ and corporeality (tajsim) to God. In accordance with a group of the later Ash'arī scholars he argues for the necessity to apply a metaphorical interpretation $\left(t^{2} w^{2} \bar{l}\right)$ of the so-called mutashābihāt, the ambiguous verses from the Qur'an. He occasionally combines his argumentations with a discussion from the viewpoint of Sufism..$^{152}$

This work may very well be the most clear-cut example of how Shādhili Sufism was intermingled with Ashari theology, which manifests, above all, in the chapter on God's aboveness. Mentioned several times in the Qur'an in such verses as: "They fear their Lord above them (min fawqihim)" [Q. 16:50], Ibn alLabbān argues that the literal meaning cannot possibly be intended when the word 'fawqa' is used, since God is free from being bound by direction. But only those endowed with spiritual insight, who have mastered their hearts (arbāb al-bașāì wa-al-qulüb), can truly comprehend that God's fawqiyya is a highness that is essential to Him rather than one that is relative, he says, for the latter variety is specific to the created world, as either highness in a physical sense or in rank. It is here where Ibn al-Labbān delves deeper into the matter, using clear elements of Shādhilī Sufism. He explains that the manifestation (tajallī) of the light of God's unity through the highness of His fawqiyya comes from God's attribute of omnipotence (qahr). Its veil (hijäb) is pure servitude ( ubüdiyya), which he bases on the verse "He [God] is the Omnipotent over His servants (wa-huwa al-qāhir fawqa ibädihi)" [Q. 6:18].153 Ibn al-Labbān then elaborates upon this as follows:

If you desire to realize that [God's] aboveness is not a spatial aboveness (fawqiyya makāniyya), but that it is rather essential aboveness (al-fawqiyy a al-haqiqiyya) by the omnipotence of [His] lordship in view of [mankind's] servitude (qahr al-rubūbiyya li-al-ubüdiyya), then reflect on the fact that He was and there was nothing with Him. He is not delimited by His creation of the heavens in an upwards direction ('uluw), nor by His creation of the earth in a downwards direction $(n u z \bar{u} l)$, nor by His

problème des attributs divins: dans la doctrine d'al-Ašcarī et de ses premiers grands disciples (Beirut: Imprimerie Catholique, 1965), pp. 231-233.

$15^{2}$ Shams al-Dīn Muḥammad b. Aḥmad Ibn al-Labbān, Izālat al-shubuhāt 'an al-āyāt wa-alahāàith al-mutashābihāt, ed. Ayman 'Abd al-Jābir al-Buhayrī and 'Amr Muṣțafā al-Wardānī (Cairo: Dār al-bayān al-'Arabī, 2002), pp. 31-35.

Ibid. p. 98 (underlining my own). 
creation of the Throne upon which He sits. On the contrary, the entire quantity of created things springs from the manifestation (tajallī) of His divine names and attributes, without physical contact with Him, and without being relative to Him in terms of aboveness, underness, or any other direction. He (T) says: "Magnify the Name of your Lord, the Most High $\left(a l-a^{\imath} l \bar{a}\right)$, Who created and shaped" [Q. 87:1-2]. Here, He is described as 'the Most High,' a status by which He is distinguished from the creation, which indicates that His Highness was established before the creation. ${ }^{154}$

Ibn al-Labbān thus leans on the notion that God existed in pre-eternity before there even was space and time, so that His aboveness can never be spatial. To get around the literal meaning he applies the Shādhilī dichotomy of rubübiyya and 'ubüdiyya by holding that God's pre-eternal fawqiyya concerns His essential omnipotence over His servants.

While I have not come across any other Shādhilī treatise that is of such a theological, kalämī nature as that of Ibn al-Labbān, there are several more indications that Ash'arism was inherent to the tă $i f a$. It is highly likely, for instance, that al-Wāsițī's shaykh Najm al-Dīn was also an adherent of the kalām school. Al-Yāfíì, himself a staunch Ash'arī, hints at this where he relates that the renowned Shāfíi Ash'arī master Ibn Daqīq al-'̄̃d (d. 702/1302) once expressed his amazement at the deviation (shudhüdh) he found in the creed of al-jīlānī regarding the divine attributes, to which Najm al-Dīn replied that the famous Hanbalī Sufi had revoked his traditionalist beliefs at the end of his life. ${ }^{155}$ Besides Najm al-Dīn, al-Yāfi'ì explicitly names al-Shādhilī as one of the great knowers of God ('ārifin ) who followed the school of Abū al-Hasan al-Ash'arī.156 Other known examples of Ash'arī Shādhilī shaykhs are al-Mursī, Ibn 'Ațā' Allah, and the latter's pupils, Ibn Bākhilā and Taqī al-Dīn 'Alī al-Subkī (d. $756 / 1355) \cdot{ }^{157}$ Furthermore, many of the scholarly authorities mentioned in the

154 Ibid. p. 99 .

155 Al-Yāfi'ì, Mir'āat, vol. 3, pp. 272-273. For Ibn Daqīq's Ash'arism, see: Taqī al-Dīn Muhammad

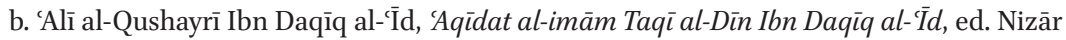
al-Ḥammādī (Tunis: Dār al-imām Ibn 'Arafa, 2012), pp. 22-30, where he discusses God's names and attributes.

156 Al-Yāfi'ì, Mir'āt, vol. 2, p. 228.

157 See: al-Iskandarī, Lațāif al-minan, p. 83, where al-Mursī is mentioned as having studied al-Juwaynī's Irshād. For Ibn 'Ațā' Allāh, see his Miftāh al-falāh, p. 37, where he stresses the importance of having a sound creed ('aqida) that is in accordance with "the school of those who are on the truth (madhhab ahl al-haqq)." That he is actually speaking of the speculative theologians becomes clear on p. 40, where he states that it is the mutakallimūn who protect the declaration of divine unity against innovators (mubtadía). Although Ibn 
sources as having been on close terms with the Shādhiliyya were also Ash'arīs, such as the above-mentioned Ibn Daqiq and his distinguished teacher in jurisprudence, Ibn 'Abd al-Salām;'158 also the renowned mutakallim, qā dī Shams alDīn Abū 'Abd Allāh Muhammad al-Iṣbahānī (d. 688/1289), ${ }^{159}$ and the Mālikī jurist, famous for his book al-Madkhal, Muhammad Ibn al-Hājj al-'Abdarī (d. $737 / 1336) \cdot{ }^{160}$

In conclusion to the above observations, I would argue that while the presence of Ash'arī doctrine among the Shādhilīs was one of al-Wāsițìs main reasons for leaving Alexandria, it is precisely in their adherence to the kalām school that we find a significant reason for their success in Alexandria - and perhaps even Egypt in general - that has mostly been overlooked in studies of the early ta $\bar{a}^{3} f a{ }^{161}$ By no means am I claiming that scholars have been unjust in laying emphasis on the Shādhiliyya's sober, sharîa a-minded Sufism to explain

'Ațā' Allāh is not explicitly mentioned as an Ash'arī, al-Ghunaymī shares my conviction that this was the case, cf. Ibn 'Ață' Allāh, p. 66. For Ibn Bākhilā, see Sharaf al-Dīn Dāwūd Ibn Mākhilā al-Iskandarī, al-Lațîfa al-marḍiyya bi-sharh du'ầ al-Shādhiliyya, ed. Muḥammad 'Abd al-Qādir Nașșār (Cairo: Dārat Karaz, 2011), where he frequently refers to Ash'arī doctrine and scholars, see: pp. 117, 142 for Abū Bakr al-Bāqillānī, 129 for Fakhr alDīn al-Rāzī, 168 for al-Juwaynī, and 193 for al-Ash'arī himself. For al-Subkī’s Ash‘arism, see al-Subkī, Țabaqāt al-shäficiyya, vol. 10, p. 146.

158 On Ibn 'Abd al-Salām, see: al-Subkī, Țabaqāt al-shäfíiyya, vol. 8, pp. 218-238, and also: 'Izz al-Dīn Ibn 'Abd al-Salām 'Abd al-'Azīz al-Sulamī, Tafsìr al-qur'ān, ed. 'Abd Allāh b. Ibrāhīm al-Wahbī (Beirut: Dār Ibn Ḥazm, 1996), vol. 1, pp. 486-487 for the Ash'arī position on of God's sitting on the Throne, and vol. 2, p. 193 on fawqiyya.

159 Al-Ișbahānī took lessons in Sufism from al-Mursī according to al-Iskandarī, Lațāàif al-minan, p. 72. For his Ash`arī background, see: al-Subkī, Țabaqāt al-shäfíiyya, vol. 8, pp. 100-102.

16o Ibn al-Hâjj's relation to the Shādhiliyya is attested to by al-Iskandarī, Lațāaif al-minan, p. 52, and whenever Ibn al-Ḥājj cites al-Shādhilī, he calls him "my master, the venerable shaykh (sayyidial-shaykh al-jalil)," words of respect he only appears to use for scholars he was affiliated with in some way, such as his own shaykh, al-Marjānī, whom he cites throughout al-Madkhal; see: Muḥammad b. Muḥammad Ibn al-Ḥājj al-'Abdarī, alMadkhal (Cairo: Maktabat dār al-turāth, date unknown), vol. 2, p. 189 and vol. 4, p. 29. Furthermore, his Ash'arism is attested to in al-Madkhal, vol. 2, pp. 147-153, where he devotes several pages to the refutation of anthropomorphism. He cites the Māliki authority Ibn Rushd al-Jadd (d. 520/1126) on p. 148, who was known to have promoted the Ash'arī creed in al-Andalus to counter literalism; see: Delfijina Serrano Ruano, "Ibn Rushd al-Jadd (d. 520/1126)," in Islamic Legal Thought: A Compendium of Muslim Jurists, ed. Oussama Arabi, David S. Powers and Susan A. Spectorsky (Leiden: Brill, 2013), pp. 310-314.

161 The relation between the Shādhiliyya and Ash'arism has been noted before, see for instance Kamran Karimullah's dissertation on the Shādhilī shaykh Aḥmad Zarruq (d. 899/1493): Ahmad Zarrūq and the Ash'arite School (dissertation M.A. McGill University, 2007), p. 31, where he notes that: "Zarrūq strongly identified the Shādhilī path with kalām: the formal principles of theology are related to the principles of the particular șüfism of Abū al-Ḥasan al-Shādhilī.” 
its successful expansion. However, the theological dimension of the context in which they thrived is equally deserving of attention. As noted in this chapter's first section, Alexandria was dominated by Shāfi'is and Mālikīs, the majority of whom adhered to the Ash'arī creed. It is, then, not difficult to imagine that, with its scholastic Sufism grounded in Ash'arī theology, combined with its attention for jurisprudence and a seemingly critical stance towards ecstatic Sufis, the Shādhilī way was easily embraced by the learned class of early Mamluk Alexandria. In addition, the țāifa's charismatic shaykhs were able to rapidly earn their place among the city's Sufi audience as well by laying claim to the western spiritual tradition. That way, the large population of Alexandrians with a Maghribi or Andalusi background could easily relate to Shādhilī Sufism. With all this in mind, one could say that the early order fit in neatly with the local normative religiosity of early Mamluk Alexandria, and that this undoubtedly contributed to its rapid growth in this context. However, for our Iraqi Sufi, who presents himself to us as having been a self-proclaimed traditionalist at that time, the distinct presence of Ash'arī theology was naturally not to his liking.

Now, as I have pointed out earlier, there was yet another reason for alWāsițì's separation from the Shādhilīs. Apart from his convinction that some of their theological beliefs were incorrect, their focus on the ta $\bar{a}$ iff's charismatic spiritual leaders also deeply troubled him. He tells us, for instance, that they would refer to al-Shādhilī by such terms as 'the spiritual axis' (al-quṭb) and 'the helper' (al-ghawth), the use of which is indeed attested to in works of early Shādhili authors. ${ }^{162}$ That such reverence bothered him is not surprising in consideration of the previously discussed criticism he had leveled against a similar attitude towards Sufi shaykhs among the Rifāīs. When it came to the Shādhilīs, however, the biggest issue for him was the essential role that the shaykhs played in their own spiritual experiences. In his autobiography he writes:

I also found that they acquire the above-mentioned states that they have from their shaykhs. Hence, they only mention their shaykhs without relying on hadith for these [states], even though there is no contradiction between them. Yet, their substance comes from the breaths (anfās) of their shaykhs, it is to them that their hearts are directed, and to them that they turn concerning their states. They depend on their [shaykhs'] spiritual unveiling (kashf), while only knowing their Lord with respect to His

162 Al-Wāsițī, Qã ida fí aṣnāf al-ta’alluh, p. 151; al-Iskandarī, Lațā̉if al-minan, al-Shādhilī is called the quṭb on p. 51 and al-Mursī on p. 76; Ibn al-Ṣabbāgh calls al-Shādhilī the ghawth and the quțb in Durrat al-asrār, p. 3 . 
antiquity and pre-eternity (qidamuhu wa-azaliyyatuhu), since He was and there was nothing with Him. ${ }^{163}$

We may note that what he viewed as excessive devotion to the shaykh in the Rifāiyya and the Shādhiliyya was most likely the mainstream position among Sufi groups in general in this epoch. There appears to have existed something of a consensus that the shaykh as a spiritual guide was essential to the novice's journey on the Sufi path. The Shādhiliyya was indeed no exception to that rule. This is exemplified most clearly by Ibn 'Ațā' Allāh's 'Unwān al-tawfì , which states that the Sufi seeker is required to find the spiritual axis (quț) of his age, as it is only through him that he may be guided unto God's proximity. ${ }^{164}$ Then, when he actually finds the axis by the grace of God, he must work hard in his service and keep him informed of his spiritual states, because the shaykh is like his spiritual physician. ${ }^{165}$ In Miftāh al-falāh Ibn 'Ațā' Allāh even relates that some Sufis are of the opinion that the disciple should imagine that his shaykh is before him when performing his remembrance of God (dhikr):

During the dhikr, [the novice] should seek the help of the shaykh's spiritual power (himma) with his heart or his consciousness [sic], believing that in doing so he is actually seeking the help of the Prophet (S), since [the shaykh] is his representative $(n \bar{a} i b) .{ }^{166}$

Thus, as scholastic and sober as the țầifa's Sufi doctrine was, al-Wāsițī had evidently developed his very own ideal image of Sufism that he could no longer consolidate with that of his Shādhilī masters. Their reliance on Ash'arī theology and devotion to their shaykhs were, in his view, serious obstructions on the pure, unadulterated journey towards God. He nevertheless felt a sense of debt to them, which he expresses poetically in the final sentence of his account of Alexandria:

But in spite of this I found something with them - and what a thing indeed! As it is said:

For the likes of Laylā a man may kill himself

Even if I'd completely renounce her! ${ }^{167}$

\footnotetext{
163 Al-Wāsițī, Riḥla, p. 35 .

164 Tāj al-Dīn Aḥmad Ibn 'Ațā̄' Allāh al-Iskandarī, 'Unwān al-tawfíq fì ādāb al-țarīq, ed. Khālid Zahrī (Beirut: Dār al-kutub al-'ilmiyya, 2004), pp. 53-54; this is also alluded to in: alIskandarī, Ibn 'Ață' Allāh (m. 709/ı309) et la naissance, p. 149.

165 Al-Iskandarī, Lațāilf al-minan, p. 114, and by the same author, Miftăh al-falāh, p. 36 .

166 Al-Iskandarī, Miftāh al-falāh, p. 21.

167 Al-Wāsiṭī, Rị̣la, p. 35.
} 
It is not mentioned why he subsequently chose to move to Cairo instead. Since the Shādhiliyya appear to have dominated Alexandria's Sufi scene one can imagine that he may have hoped to once again make a fresh start, this time in the capital of Egypt. However, what he found there among the Sufis was many times more loathsome to him than what he had found among the Shādhiliyya, and would finally push him away from Egypt for good. 